\title{
The effects of teaching strategies, methods and techniques on creative thinking: A meta-analysis study
}

\author{
Sevda DOLAPÇIOĞLU ${ }^{* a}$, Burcu GÜRKAN ${ }^{* * b}$ \\ ${ }^{a}$ Hatay Mustafa Kemal University, Faculty of Education, Hatay/Turkey \\ ${ }^{\mathrm{b}}$ Hasan Kalyoncu University, Faculty of Education, Gaziantep/Turkey
}

Article Info

DOI: $10.31704 /$ ijocis.2020.006

Article History:

Received 20 March 2020

Revised 30 March 2020

Accepted 20 May 2020

Online 10 June 2020

\section{Keywords:}

Teaching strategies, methods and techniques,

creative thinking,

creativity.

\begin{abstract}
This study aims to unify the effect size of experimental studies that were carried out to determine the effect of teaching strategies, methods and techniques on creative thinking skills, and to find out whether this effect size was of significant differences for certain variables. A meta-analysis of 19 studies investigating the effect of teaching strategies, methods and techniques published between 2005-2019 on students' creative thinking skills was conducted. The study results revealed that teaching possessed a moderate effect on students' creative thinking skills varying considerably based on the grades the study group and the discipline dealt with in the study yet no meaningful difference in terms of the country it was carried at and no experimental effect for the applied teaching strategies, methods and techniques.
\end{abstract}

Article Type:

Research paper

\section{Öğretim strateji, yöntem ve tekniklerinin yaratıcı düşünmeye etkisi: Bir meta- analiz çalışması}

Makale Bilgisi

DOI: 10.31704/ijocis.2020.006

Makale Geçmişi:

Geliş 20 Mart 2020

Düzeltme 30 Mart 2020

Kabul 20 Mayıs 2020

Çevrimiçi 10 Haziran 2020

Anahtar Kelimeler:

Öğretim strateji, yöntem ve teknikleri, yaratıcı düşünme, yaratıcılık.

Makale Türü:

Özgün Makale
Öz

Bu araştırmada öğretim strateji, yöntem ve tekniklerinin yaratıcı düşünme becerisi üzerindeki etkisinin belirlenmesi amacıyla yapılan deneysel çalışmaların etki büyüklüklerinin birleştirilmesi ve bu etki büyüklüğünün çeşitli değişkenlere göre anlamlı bir farklılık gösterip göstermediğinin incelenmesi amaçlanmıştır. 2005-2019 yılları arasında yayınlanan öğretim strateji, yöntem ve tekniklerinin öğrencilerin yaratıcı düşünme becerisi üzerine etkisini inceleyen 19 araştırmanın meta analizi yapılmıştır. Araştırma sonucunda öğretim strateji, yöntem ve tekniklerinin öğrencilerin yaratıcı düşünme becerisi üzerinde orta düzeyde bir etkiye sahip olduğu; bu etkinin çalışma grubunun öğrenim kademesine ve çalışmada ele alınan disipline göre anlamlı olarak farklılaşırken, yayınlanan ülkeye ve deneysel etki için uygulanan öğretim strateji, yöntem ve tekniğine göre anlamlı olarak farklılaşmadığı ortaya çıkmıştır.
*Author: sdolapcioglu@mku.edu.tr
** Author: burcu.gurkan@hku.edu.tr Orcid ID: https://orcid.org/0000-0002-2707-1744 Orcid ID: https://orcid.org/0000-0003-3942-6407 


\section{Introduction}

When individuals want to solve a problem or meet dead-ends, they either make use of the available solutions yet mainly seek for create new ways. This brings about the need for new ideas, thoughts and products in various aspects of daily life such as technological and scientific fields. The striking point of the 21st century is the fact that the societies that make groundbreaking improvements and are pioneers in education, art and science have become prominent. These societies inherently possess and implement innovative thinking and culture skills. Innovative thinking refers to doing different things, producing or using new ideas/behaviors (Damanpour \& Schneider, 2009; Reiman \& Dotger, 2008; Stenberg, 2017). Innovative behavior is a process, in which original ideas are generated, created, developed, applied, introduced, realized and modified (Thurlings, Evers \& Vermeulen, 2014). Innovation and creativity are associated with each other in creativity terms to produce and develop worthwhile things (Stenberg, 2017; Taylor, 2017). Innovation is the creation of novelty, and it is related to creative thinking. But creativity should not be perceived as a skill which is only related to science and art. Creativity is also an important life skill. Thus, mental effort and production is necessary for the solution of any big, small or medium-size problems encountered in daily life.

Talented individuals generate knowledge by using their skills and influence society by helping them understand innovations. Therefore, it is necessary to support environments that enable individuals to select, acquire and use proper skills (Organization for Economic Co-operation and Development, [OECD], 2015). It is crucial for societies to train individuals to formulate creative solutions for increasingly complex social problems. Creativity in education is acknowledged as an essential skill in the 21st century (Kupers, Lehmann-Wermser, McPherson \& van Geert, 2019; Lin \& Shih, 2016; Tan, 2000). As Sungur (1997) expressed, the purpose of education is "to raise people who have the talent to produce new things rather than repeating what previous generations did" (p. 31). Today, various institutions, associations or countries focus on developing thinking skills and integrating creative thinking skill training in the curricula. For example, UNICEF concentrates on student-centered education and creative thinking skills emphasized training of students (Chakera \& Tao, 2019). In the Turkish elementary and secondary school curriculum, creativity is referred as a critical living and engineering skill (Ministry of National Education [MoNE], 2020). Singapore's education system that draws attention with its high ranks in PISA and TIMMS exams, points out 21st century skills and curriculum which emphasize developing creativity and innovative thinking (Ministry of Education Singapur, [MoES], 2020). Various instructional principles and methods are employed to develop students' creative thinking skills. The goal of this research is to analyze the effect of teaching methods and techniques used at different disciplines, country and age level for creative thinking skill improvement.

\section{Creativity and Creative Thinking}

Creativity is generating new, different, original, valuable and unique ideas/actions. Fed on emotions such as curiosity and the desire to discover, creativity is a cognitive ability in which solutions to problems are sought and unique synthesizing is made between the situations that have no common links (Craft, 2001; Csikszentmihalyi, 1997; Forrester, 2008; Harris, 1998; Keun \& Hunt, 2006; San, 2003). Creativity is the process of resolving problems by creative thinking (Cash, Rae, Steel \& Winkler, 2012). Creative thinking is "the source of innovation and change as well as the extension of the future" (Yıldırım, 2002, p. 7). Torrance (1965) defined creative thinking as perceiving challenges, problems, knowledge gaps, missing elements and uneven things, making predictions about them, generating a hypothesis about the lacking fact, assuming and assessing a hypothesis, testing, contemplating, re-testing and conveying the results. Another description is that effected creativity is the emergence of original and valuable ideas related to creativity with innovation and imagination. Social creativity should represent the congenital creativity potential of all individuals 
and creativity can emerge in any kind of fields (science, mathematics etc.) rather than just art (music, dance, painting) (Robinson, 2017). Lipman (1995), points out that students are to think resourcefully to become a high-level thinker. Students' creative thoughts that also include inventing consist of artistic and scientific enquiry processes. As understood from the definition and clarifications, creativity is related to imagining, designing and creating innovations. People can solve problems, thus, shape their futures with these congenital skills.

It is improper to regard creative thinking itself as a single skill. There are various ways to explore and reflect on creativity. For example, creativity can appear when a single idea is considered around two conflicting reference frameworks. One of them is life; and the two conflicting reference frameworks are material and mind (Low, 2006). Creative thinking is multi-dimensional notion and contains multiple sub-cognitive competences/properties. Cognitive competencies such as imagining, flexibility, fluency, originality, sensitivity, synthesis are among the characteristics of creative thinking (Allen \& Thomas, 2011; Chang, Li, Chen \& Chiu, 2015; Lin \& Wu, 2016; Perry \& Karpova, 2017; Torrance, 1965; Yarbrough, 2016). Torrance (2018) developed an instrument to identify creative thinking skills and this test consisted of five sub-structures as "fluency, originality, elaboration, abstractness of titles, resistance to premature closure". The creative thinking test developed by Gilford (1950) included "originality, fluency, flexibility and elaboration" dimensions of creativity (as cited in Varzaneh \& Baharlooie, 2015). Each sub-structure is one of the aspects of creative thinking that can indicate creativity either separately or in total. In fact, it depends on what researchers and educators want to develop and measure. In this study, the studies included in the analysis investigated certain dimensions of creativity, which resulted in total creativity scores and interpretation of creative thinking skill.

Creativity capacity is multi-dimensional phenomenon and can be influenced and developed by different variables. It is reasonable to assume that stimulating creativity has as many as ways as the dimensions of creativity (Sak \& Oz, 2010). Various education programs/curricula have been recommended to develop creative thinking processes (Craft, 2001); specific approaches and techniques have been applied for supporting various aspects of creativity (Sak \& Oz, 2010). Jeffrey and Craft (2004) reported that students adapt themselves to teachers' teaching approach and creativity is affected by teachers' creative teaching strategies. Sternberg (2003) expressed that there might be different types of creativity, teachers should reward all kinds of creativity and decisions to reinforce students' creativity, which should be regarded as important steps. To Beghetto, Kaufman and Baer (2015), it is critical that the teachers present a real content to expand students' creative thinking in a specific branch and at the same time, to develop cognitive skills specific to that field. Wu and Lin (2001) emphasized that creative thinking should involve versatility, based on active teaching strategies and reflect a student-centered structure (as cited in Ku \& Kuo, 2014). Researchers have studied strategies supporting the development of creative thinking and provided following recommendations:

- Bono (1999) claimed that six hat thinking technique designed to improve multi-directional thinking can develop creativity.

- Torrance (1972, 1998 as cited in Shaughnessy, 1998) remarked that strategies such as problem-solving, creative problem-solving, creative research, media and reading education, visual arts, creative drama, socio-drama, role-playing and self-learning supports creative thinking.

- Gilbert (1992) recommended relating, imagination, brainstorming, organization, analogy and metaphor and re-conception to establish creativity.

- Horng, Hong, Chanlin, Chang and Chu (2005) mentioned that student-centered activities, forming connections between teaching content and real-life, asking open-ended questions, using technology and multimedia and real-life experiences enhances creative thinking. 
- Kind and Kind (2007) asserted that open inquiry, creative problem-solving, creative writing, forming metaphor and analogy practices can be useful for encouraging creativity.

- Buzan and Buzan (2011) suggested that using mental mapping technique contributes to the development of creative thinking.

- Kampylis and Berki (2014) found developing creative thinking for each lesson, organizing learning environment to support creative thinking, asking open-ended questions, providing authentic learning experiences, cooperating, applying education technologies effectively, making mistakes and preparing activities that ensure taking risks are necessary for the adoption of creative thinking.

The common issue of these suggestions are being student-centered, ensuring students' active mental participation and assuming questioning as an essential component. OECD (2016) classified teaching practices as "active learning strategies, cognitive activation strategies and teacher-directed teaching strategies". Teacher directed teaching strategies point that the burden of the class is on the teacher. In this process, there are target explanation, presenting the summary of the previous lessons and asking reality-based questions. Active learning strategies refer to the students being responsible for their own learning, discussion task, group work, cooperation, using information and communication technologies and individual learning environment development (OECD, 2016). Cognitive activation strategies include teaching strategies that directly develop high-level thinking skills such as motivation, critical thinking, problem-solving and decision-making (OECD, 2016). In this study, teaching applications that intend to improve creative thinking were categorized under active learning strategies and cognitive activation strategies as these practices were not teacher-centered applications. For instance, "tablet-based interactive class" teaching technique by Kim, Park, Yoo and Kim (2016) was listed among active learning strategies and "problem-based learning" by Ülger and Imer (2013) was considered one of cognitive activation strategies.

Sternberg (2006) implied that creativity is affected by six interrelated sources as "intellectual skills, knowledge, thinking styles, personality, motivation and environment". Researchers still continue to study on the methods and ways that control creative thinking. Following a review of the related literature, it can be seen that almost every country around the world have investigated creativity (Gocłowska \& Crisp, 2013; Lin \& Wu, 2016; Marušić \& Sliško, 2014; Mokaram, Al- Shabatat, Fong \& Abdallah, 2011; Rábanos \& Torres, 2012; Rezaei \& Zakariaie, 2011; Wojciechowski \& Ernst, 2018; Yiğit \& Erdoğan, 2008) at various disciplines and education levels such as science, English, visual arts, education technologies (Al-Masri, 2008; Chang, 2013; Koray \& Köksal, 2009; Ülger \& İmer, 2013); in terms of the independent influences of teaching practices such as problem-based learning, brainstorming, online problem-solving, and six hat thinking technique on creative thinking (Al-Masri, 2008; Chang, 2013; Yaman \& Yalçın, 2005; Ziadat \& Al Ziyadat, 2016). For example, in a study with university students Şensoy and Yıldırım (2017) found that research-investigation-based teaching technology and material development class had no effect on creative thinking. Sayan and Hamurcu (2018) identified no significant difference in creative thinking in favor of experiment group in terms of the materials developed in science class. When other studies included in this study were reviewed, meaningful differences in favor of the experiment group were observed in classes where active learning and cognitive activation strategies were applied. In these studies, the effect of only one teaching method on creativity was tested, and the results showed that certain methods affected creative thinking while others had no impact. Then, how do teaching strategies, methods and techniques support the development of creativity? When the related literature was checked, there were no studies on the holistic effect of teaching strategies, methods and techniques on creative thinking. The purpose of this study is to uncover the effects of teaching strategies, methods and techniques on creative thinking. Thus, it is believed that the common effect of them creativity and their strength to predict creativity can be identified. In this research, answers to the following questions were sought: 
- What are the effects of instructional strategies, methods and techniques on creative thinking skills?

- Do teaching strategies, methods and techniques for the development and improvement of creative thinking skills show significant differences in terms of the country the research is done, discipline and education level of the study group?

\section{Method}

This study that aimed looking into the effects of teaching strategies, methods and techniques on creative thinking adopted a meta-analysis method, "which requires categorization of similar studies on a subject, theme or study field with certain criteria, and to collect and interpret qualitative findings in these studies accordingly" (Dinçer, 2014, p. 4). In meta-analysis method, the results derived from multiple studies are taken into consideration rather than only one research (Shelby \& Vaske, 2008) for more comprehensive outcomes (Büyüköztürk, Kılıç Çakmak, Akgün, Karadeniz \& Demirel, 2014). Since the study investigated the effects and explanatory role of teaching strategy, method and techniques on creative thinking, a meta-analysis method was adopted.

\section{Data Collection}

With the aim to find answers to questions of this study, national and international publications that investigated the impacts of teaching strategies, methods and techniques on creative thinking between 2005 and 2019 were reviewed. In this sense, three databases, ERIC, Google Scholar and TR Dizin (ULAKBIM) were used so as to access to national and international studies easily. Publications were revised by using both English and Turkish keywords of "yaratıcı düşünme", "yaratıcılık", "creative thinking" and "creativity". The beginning date of the reviews was specified as 2005 when the educational philosophy and teaching approach in Turkish elementary school curriculums changed in that year. The first database review started on 25th December 2018 and completed between 25th and 30th May 2019 following a last review.

\section{Inclusion Criteria}

Following the type of the related keywords to the databases (ERIC, Google Scholar, TR Dizin), 133 papers were detected for analysis. The following criteria were considered to include those papers in this study.

a. Study Method: Experimental or semi-experimental studies that investigated the effects of teaching applications on creative thinking skills were chosen.

b. Study Publication Type: This study only included articles published in scholarly journals.

c. Sample Properties: In experimental or semi-experimental studies, the ones with at least two groups were selected and the studies with experiment and control groups were included.

d. Comparison: The studies that compared experiment and control groups were included.

e. Data Analysis: The studies in which parametric tests were applied, were included.

f. Creative Thinking Total Score: The researches that analyzed the total value of teaching applications on creative thinking were included in this study.

g. Structure of Data Collection Instrument: Studies that utilized similar tools in terms of measuring creativity were included.

h. Qualitative Data: Studies with (N, X, SS, F, P, t... etc.) values to calculate standardized effect sizes in a meta-analysis process or the ones with data that enable effect size calculation were included in this study. The sample of this study was composed of 21 papers. The flow chart for the process of being included in the analysis is given in Figure 1. 


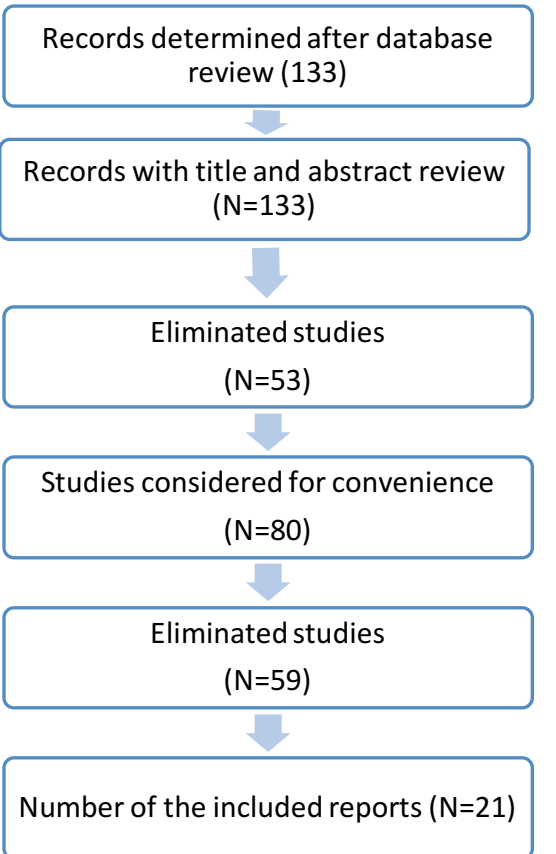

33 studies for semi-experimental/experimental pattern 10 studies for qualitative study pattern

$\rightarrow 9$ studies for describing different dependent variable 1 study for being an exact copy were eliminated.

Figure 1. Flow chart for inclusion process

\section{Data Coding}

The studies based on the inclusion criteria were selected and coded. During coding stage (1) Study no, (2) Database, (3) Number of authors, (4) Study country, (5) Study year, (6) Academic level, (7) Academic degree/department, (8) Study discipline, (9) Independent variable, (10) Data collection tool, (11) Data analysis and (12) N, X, SS, F, P, t...etc. statistic values were uploaded in a Microsoft Excel file. Table 1 presents the properties of these studies. 
Table 1.

Demographic Properties of the Studies Included in Meta-Analysis

\begin{tabular}{|c|c|c|c|c|c|c|c|c|c|}
\hline No & Author & Year & Comparison no & Country & $\begin{array}{c}\text { Data } \\
\text { instrument }\end{array}$ & Discipline & $\begin{array}{l}\text { Education } \\
\text { level }\end{array}$ & $\begin{array}{l}\text { Teaching } \\
\text { strategies }\end{array}$ & $\begin{array}{c}\text { Sample number } \\
\text { (Experiment+Control) }\end{array}$ \\
\hline 1 & Yaman and Yalçın & 2005 & 1 & Turkey & TYDT & Physical Sciences & University & Active & $105+115$ \\
\hline 2 & Yiğit and Erdoğan & 2008 & 1 & Turkey & TYDT & Social Sciences & Secondary & Active & $21+21$ \\
\hline 3 & $\begin{array}{l}\text { Erdoğan, Akkaya and } \\
\text { Çelebi Akkaya }\end{array}$ & 2009 & 1 & Turkey & TYDT & Mathematics & Secondary & Cognitive & $27+28$ \\
\hline 4 & Koray and Köksal & 2009 & 1 & Turkey & TYDT & Physical Sciences & University & Cognitive & $44+46$ \\
\hline 5 & Karataş and Özcan & 2010 & 1 & Turkey & TYDT & Educational Sciences & Secondary & Cognitive & $21+20$ \\
\hline 6 & $\begin{array}{l}\text { Mokaram, Al-Shabatat, } \\
\text { Fong and Abdallah, }\end{array}$ & 2011 & 1 & Malesia & TYDT & Educational Sciences & University & Active & $25+25$ \\
\hline 7 & Rezaei and Zakariaie & 2011 & 4 & Iran & TYDT & Art Education & Secondary & Active & $32+31$ \\
\hline 8 & Chang & 2013 & 2 & Taiwan & $\begin{array}{c}\text { Creative } \\
\text { Thinking Test }\end{array}$ & Educational Sciences & Primary & Active & $57+54$ \\
\hline 9 & Ülger and Imer & 2013 & 1 & Turkey & TYDT & Art Education & Secondary & Active & $36+36$ \\
\hline 10 & Yangın & 2014 & 1 & Turkey & TYDT & Physical Sciences (Biology) & University & Cognitive & $74+78$ \\
\hline 11 & AlMutairi & 2015 & 1 & Kuwait & TYDT & Thinking Education & Secondary & Cognitive & $47+51$ \\
\hline 12 & Karataş and Özcan & 2015 & 1 & Turkey & TYDT & Educational Sciences & University & Active & $24+23$ \\
\hline 13 & Varzaneh and Baharlooie & 2015 & 1 & Iran & $\begin{array}{l}\text { Gilford Creative } \\
\text { Thinking Scale }\end{array}$ & Language Education (English) & $\begin{array}{l}\text { High } \\
\text { School }\end{array}$ & Active & $60+60$ \\
\hline 14 & Ziadat and Al Ziayadat & 2015 & 1 & Jordan & TYDT & Language Education (Arabic) & Secondary & Cognitive & $27+32$ \\
\hline 15 & Dikici Sığırtmaç & 2016 & 1 & Turkey & TYDT & Chess Education & Preschool & Active & $41+46$ \\
\hline 16 & Kıncal, Avcu and Kartal & 2016 & 1 & Turkey & TYDT & Social Sciences (Geography) & $\begin{array}{l}\text { High } \\
\text { School }\end{array}$ & Active & $20+20$ \\
\hline 17 & Kim, Park, Yoo and Kim & 2016 & 1 & $\begin{array}{l}\text { South } \\
\text { Korea }\end{array}$ & TYDT & Educational Sciences & Secondary & Active & $137+125$ \\
\hline 18 & Karaca and Koray & 2017 & 1 & Turkey & TYDT & Physical Sciences & Secondary & Cognitive & $19+20$ \\
\hline 19 & Şensoy and Yıldırım & 2017 & 1 & Turkey & TYDT & Educational Sciences & University & Active & $45+47$ \\
\hline 20 & Al Masri & 2018 & 1 & Jordan & TYDT & Language Education (English) & $\begin{array}{l}\text { High } \\
\text { School }\end{array}$ & Cognitive & $84+84$ \\
\hline 21 & Sayan and Hamurcu & 2018 & 1 & Turkey & TYDT & Physical Sciences & Primary & Active & $38+38$ \\
\hline
\end{tabular}




\section{Data Analysis}

\section{Procedure}

The researchers computed the effect size of the studies included in the meta-analysis. Effect size can be measured with Cohen d, Hedge's g and Glass g values (Akbaş, Atalan Ergin \& Tatlı, 2019). In this study, effect sizes were calculated as Hedge's g value. The significance level for the results was .05. Following classifications were adopted to interpret the effect size of the studies (Cohen, 1988):

$0.20 \leq$ effect coefficient $<0.50$

small level

$0.50 \leq$ effect coefficient $<0.80$ medium level

$0.80 \leq$ effect coefficient large level

Heterogeneity test was administered to find out which model (fixed, random) will be used for general effect size calculation. For fixed effect model studies, it was assumed that the universe sizes were same and standard deviations were equal to zero while for random effect model, individual universe sizes were different and the standard deviation wasn't equal to zero. If heterogeneity tests results revealed homogenous results for individual studies, fixed effect model was applied, and for heterogeneous results, a random effect model was used (Dinçer, 2014). Accordingly, as p-value from heterogeneity test results was significant and $Q$ value corresponding to the degree-of-freedom value in $\mathrm{X} 2$ table was larger, the random effect model was adopted.

Three variables that might affect the calculated general effect size were identified. These were "study country, study group education level and study discipline". Categorical moderator analysis was conducted on a random effect model to see if the general effect size showed a significant difference for the identified variables. In this study, the Comprehensive Meta-Analysis (CMA) program was applied during the meta-analysis process.

\section{Publication Bias}

Publication bias is one of the key factors influencing the meta-analysis results. Publication bias might lead to include studies in the meta-analysis that only focus on a particular result or obtained from a limited review (Dinçer, 2014). Within this context, the researchers conducted the review on various databases and tried to access all related studies. Expert views with previous meta-analysis experience were referred to when the criteria for excluding the obtained studies were specified. A variety of methods are adopted to test whether studies included in the meta-analysis have publication bias. The most common method is investigating the cone graphic (Dinçer, 2014). In this study, firstly cone graphic was examined. Then, publication bias was statistically investigated by using Egger's linear regression method. Analysis with Egger's linear regression method pointed out that there was no publication bias as $\beta 0=0$ hypothesis was not significant (Egger, Smith, Schneider \& Minder, 1997).

\section{Results}

\section{Publication Bias}

Firstly, cone graphic was analyzed to determine whether the general effect size of the studies was derived from publication bias. The line in the middle of this graphic shows the general effect size. When there is no publication bias, it is anticipated that the effect size of individual studies is around this line and inside the cone (Dinçer, 2014). 


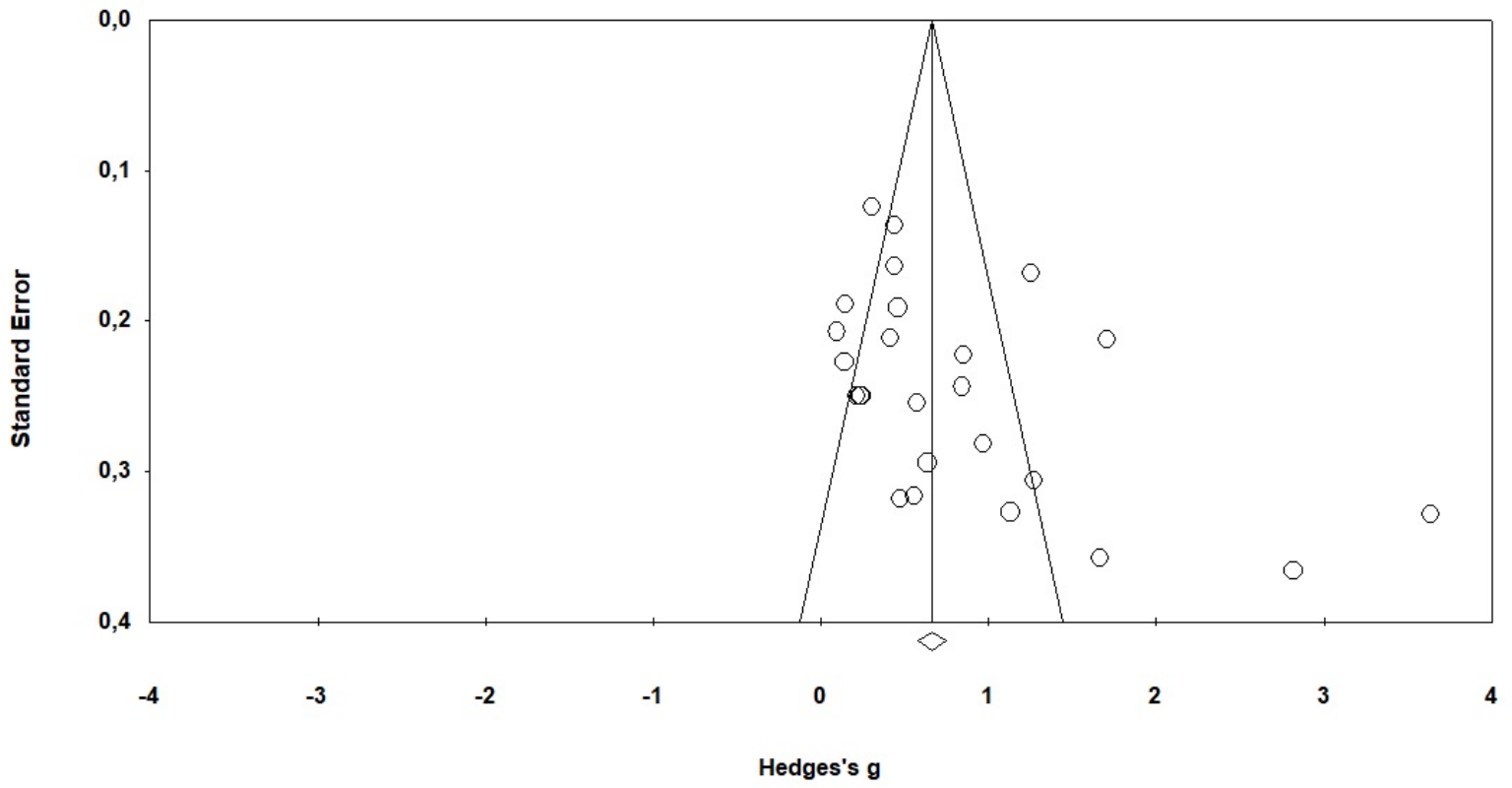

Figure 2. Cone graphic

When the cone graphic in Figure 2 was scrutinized, it was noticed that the general effect size of the individual studies distributed asymmetrically and some of the effect sizes were outside the cone line, which refers that there might be publication bias; however, publication bias statistic should be checked to ensure reliability (Dinçer, 2014). Egger's intercept test was applied to decide whether cone graphic was significant. Egger's intercept test results are presented in Table 2.

When the cone graphic in Figure 2 was scrutinized, it was noticed that the general effect size of the individual studies distributed asymmetrically and some of the effect sizes were outside the cone line, which refers that there might be publication bias; however, publication bias statistic should be checked to ensure reliability (Dinçer, 2014). Egger's intercept test was applied to decide whether cone graphic was significant (Card, 2012). Egger's intercept test results are presented in Table 2.

Table 2.

Egger's Intercept Test Result

\begin{tabular}{ccccccc}
\hline $\begin{array}{c}\text { Intercept value } \\
\left(\mathrm{B}_{\mathbf{0}}\right)\end{array}$ & Standard error & Lower-limit & Upper-limit & t-value & df & p-twin-tail \\
\hline 4.630 & 1.844 & 0.815 & 8.556 & 2.510 & 23 & 0.01 \\
\hline
\end{tabular}

The intercept value (4.630) was significant ( $p \leq .05$ as seen in Table 2 ). In this sense, it can be inferred that there was a publication bias in this study. With the aim to find out whether studies included outliers, forest graphic and standard residuals of all the included were tested. 


Study
Yaman and
Yiğit and
Dikici
Rezaei and
Rezaei and
Rezaei and
Rezaei and
Karaca and
Almutairi,
Ziadat and
Mokaram AI
Al Masri,
Kim and
Koray and
Karataş and
Erdoğan
Yangın
Kıncal and
Şensoy and
Sayan and
Varzaneh
Yu-Shan
Yu-Shan
Ülger and
Karataş and

Effect Size and Confidence Interval \%95

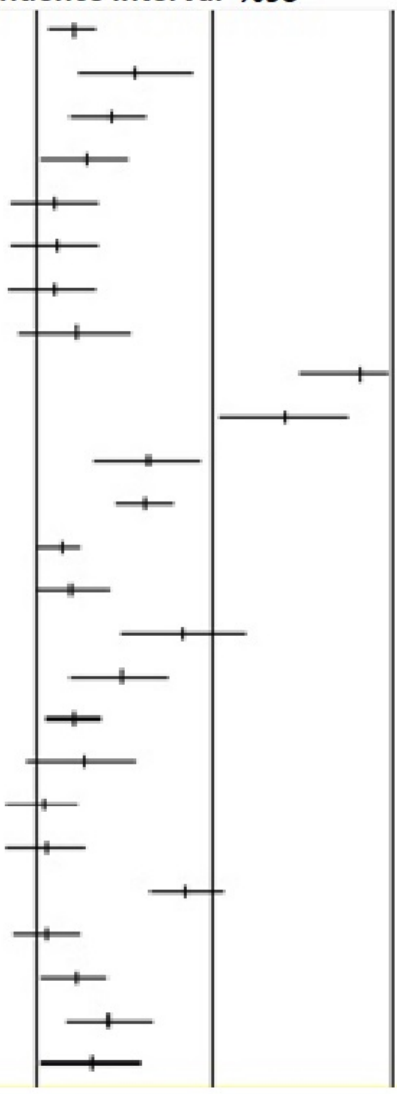

Standard Residual

$-0.62$

0.44

0,04

$=0,39$

$-0,90$

$-0,89$

$-0.94$

$-0,52$

4,07

2.81

0,65

0.67

$-0,85$

$-0,64$

1.19

0.21

$-0.61$

$-0,39$

$-1,14$

$-1,06$

1,37

$-1,07$

$-0,58$

0.02

$-0,28$

Figure 3. Forest graphic and standard residuals

As shown on Figure 3, the study with the narrowest confidence range was the research by Kim, Park, Yoo and Kim (2016) and the largest confidence range was the one by Ziadat and Al Ziayadat (2015). In the forest graphic, it is clear that these two studies had 4.07 and 2.81 standard residual values respectively, differentiated from other studies, which resulted in acting as outliers. One of the researches that might have an outlier value was carried out by Al Mutairi (2015) on secondary school students and published in Kuwait. Another study was led by Ziadat and Al Ziayadat (2015) on secondary school students in the language education field and published in Jordan. Table 3 presents the heterogeneity test results when these studies were eliminated from this study.

Table 3.

Heterogeneity Test Results Obtained After Excluding These Studies

\begin{tabular}{|c|c|c|c|c|c|}
\hline The Excluded Study & $\mathbf{N}$ & $\mathbf{Q}$ & df & $\mathrm{x}^{2}$ & $\mathrm{I}^{2}$ \\
\hline 1. None was excluded & 25 & 214.983 & 24 & 36.415 & 88.836 \\
\hline 2. Almutairi (2015) was excluded & 24 & 131.250 & 23 & 35.172 & 82.476 \\
\hline 3. Ziadat and Al Ziayadat (2015) were excluded & 24 & 179.719 & 23 & 35.172 & 87.202 \\
\hline 4. Both were excluded & 23 & 94.199 & 22 & 33.924 & 76.645 \\
\hline
\end{tabular}

As viewed from Table 3, Q1=214.983 value obtained from heterogeneity test with 25 comparisons possessed Q2=131.250 value when Almutairi (2015) was excluded; the value was Q3=179.719 when 
Ziadat and Al Ziayadat (2015) was removed; and the value was Q4=94.199 when both studies were eliminated.

When forest graphic, standard residual values and the effects of eliminating a study on $Q$ values were taken into account, these studies were determined to possess outlier characteristics and it was appropriate to remove these studies. Cone graphic was investigated to reveal whether the remaining 19 individual studies (23 comparisons) were of publication bias.

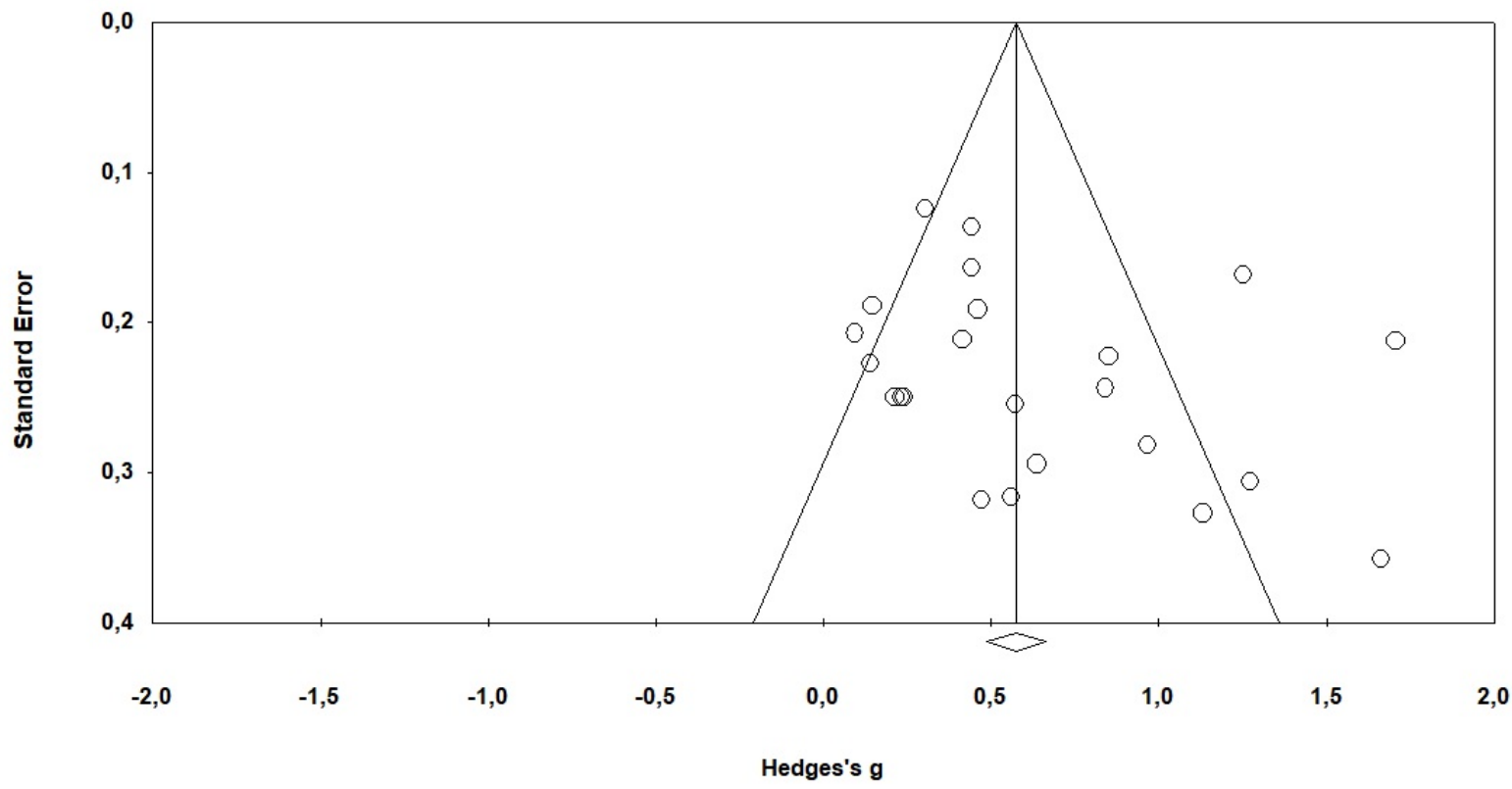

Figure 4. Cone graphic

To the Figure 4, it can be seen that the general effect size distributed asymmetrically and some of the effect sizes were outside the cone line, which could indicate that publication bias issue continues. Egger's intercept test was performed to check if the cone graphic distribution was significant. The test was re-applied and the results were demonstrated in Table 4.

Table 4.

Egger's Intercept Test Result

\begin{tabular}{ccccccc}
\hline $\begin{array}{c}\text { Intercept } \\
\text { value }\left(B_{0}\right)\end{array}$ & Standard error & Lower-limit & Upper-limit & $\boldsymbol{t}$-value & $\boldsymbol{d f}$ & $\boldsymbol{p}$-twin-tail \\
\hline 2.163 & 1.492 & -0.940 & 5.268 & 1.449 & 21 & 0.16 \\
\hline
\end{tabular}

As seen in Table 4, the intercept value was calculated as 2.163. Considering the significance level of the intercept value, it can be understood that the value was insignificant at $95 \%$ confidence level ( $p>$.05). Accordingly, it is reasonable to express that there is no publication bias in the remaining 19 individual studies (23 comparisons).

\section{Properties of the Studies Included in the Meta-Analysis}

Within the scope of this study, 19 individuals were evaluated and a total of 23 comparisons were made. All the studies included in this research were published as papers. A total sample size of these studies was 1827 individuals. The experiment groups consisted of 910 individuals and the control 
groups included 917 individuals. The information related to the country the study was carried at, the study groups' educational level and discipline are shown in Table 5 below.

Table 5.

Frequency and Percentage of the Published Country, Study Group Education Level and Study Discipline for Studies Included in the Meta-Analysis

\begin{tabular}{|c|c|c|c|}
\hline Variable & & $f$ & $\%$ \\
\hline \multirow{6}{*}{ Country } & Turkey & 13 & 68.42 \\
\hline & Iran & 2 & 10.53 \\
\hline & Jordan & 1 & 5.26 \\
\hline & Malesia & 1 & 5.26 \\
\hline & Taiwan & 1 & 5.26 \\
\hline & South Korea & 1 & 5.26 \\
\hline \multirow{7}{*}{ Discipline } & Educational Sciences & 6 & 31.58 \\
\hline & Physical Sciences & 5 & 26.31 \\
\hline & Language Education & 2 & 10.53 \\
\hline & Social Sciences & 2 & 10.53 \\
\hline & Art Education & 2 & 10.53 \\
\hline & Mathematics & 1 & 5.26 \\
\hline & Chess Education & 1 & 5.26 \\
\hline \multirow{3}{*}{ Education Level } & Primary & 10 & 52.63 \\
\hline & University & 6 & 31.58 \\
\hline & Secondary & 3 & 15.79 \\
\hline \multirow{2}{*}{ Teaching Strategies } & Active Learning Strategy & 13 & 68.42 \\
\hline & Cognitive Activation Strategy & 6 & 31.58 \\
\hline
\end{tabular}

As demonstrated in Table 5, 68.42\% of the included studies were published in Turkey, $10.53 \%$ in Iran, 5.26\% in Jordan, 5.26\% in Malesia, 5.26\% in Taiwan and 5.26\% in South Korea. In terms of the disciplines, $31.58 \%$ of the researches were in educational science, $26.31 \%$ in physical sciences, and $10.53 \%$ in language education, $10.53 \%$ in social sciences, $10.53 \%$ in art education, $5.26 \%$ in mathematics and $5.26 \%$ chess education fields. Regarding the education level of the study groups, it was found that $52.63 \%$ were primary school, $31.58 \%$ were university and $15.79 \%$ were secondary school. In terms of teaching strategies, $68.42 \%$ studies made use of active learning strategies and $31.58 \%$ studies applied cognitive activation strategies.

\section{Heterogeneity Test}

Table 6 demonstrates the heterogeneity values, average effect size and confidence interval for fixed and random effect model of the included studies. 
Table 6

Effect Size and Heterogeneity Test Results of the Studies

\begin{tabular}{|c|c|c|c|c|c|c|c|c|c|c|}
\hline \multirow{2}{*}{ Model Type } & \multirow{2}{*}{$\mathbf{N}$} & \multirow{2}{*}{ Effect Size } & \multirow{2}{*}{$\begin{array}{l}\text { Std. } \\
\text { Error }\end{array}$} & \multicolumn{2}{|c|}{$\begin{array}{c}\text { \%95 Confidence } \\
\text { Interval }\end{array}$} & \multirow{2}{*}{$x^{2}$} & \multicolumn{4}{|c|}{ Heterogeneity } \\
\hline & & & & $\begin{array}{l}\text { Lower- } \\
\text { limit }\end{array}$ & $\begin{array}{l}\text { Upper- } \\
\text { limit }\end{array}$ & & $\mathbf{Q}$ & df & $\mathbf{p}$ & $\mathrm{I}^{2}$ \\
\hline Fixed E. M. & 23 & 0.575 & 0.044 & 0.488 & 0.662 & 33.924 & 94.199 & 22 & 0.00 & 76.645 \\
\hline Random E. M. & 23 & 0.631 & 0.095 & 0.445 & 0.818 & & & & & \\
\hline
\end{tabular}

As understood from Table 6 , the heterogeneity test was significant ( $p \leq .05)$. Q value was measured as 94.199 with 22 degrees-of-freedom. In X2 table, the critical value for 22 degrees-of-freedom at 0.05 level was approximately 33.924. Accordingly, the Q value (94.199) was larger than the critical value (33.924), which indicated that effect size distribution had a heterogeneous structure. 12 index value of $76.645 \%$ implied that heterogeneity between the studies was at a "high" level. Thus, the study data were analyzed with random effect model. Forest graphic of the effect size of the studies calculated with the random effect model is given in Figure 5.

\begin{tabular}{|c|c|c|c|c|c|c|c|}
\hline \multirow[t]{2}{*}{ Study name } & \multicolumn{7}{|c|}{$\underline{\text { Statistics for each study }}$} \\
\hline & $\begin{array}{l}\text { Hedges's } \\
\text { g }\end{array}$ & $\begin{array}{c}\text { Standard } \\
\text { error }\end{array}$ & Variance & $\begin{array}{c}\text { Lower } \\
\text { limit }\end{array}$ & $\begin{array}{c}\text { Upper } \\
\text { limit }\end{array}$ & Z-Value & p-Value \\
\hline Yaman and Yaicin, 2005 & 0,442 & 0,136 & 0,019 & 0,175 & 0,709 & 3,248 & 0,001 \\
\hline Yigit and Erdagan, 2008 & 1,133 & 0,327 & 0,107 & 0,492 & 1,774 & 3,465 & 0,001 \\
\hline Dikio Sigrumsc, 2016 & 0,851 & 0.222 & 0,049 & 0,415 & 1,287 & 3,826 & 0,000 \\
\hline Rezasi and Zaksrisie, 2011a & 0,573 & 0.254 & 0,065 & 0,075 & 1,071 & 2,256 & 0,024 \\
\hline Rezasi and Zaksariae, 2011b & 0,234 & 0,250 & 0,062 & $-0,256$ & 0,723 & 0,936 & 0,349 \\
\hline Rezasi and Zaksriaie, 2011e & 0,242 & 0,250 & 0,062 & $-0,259$ & 0,731 & 0,967 & 0,334 \\
\hline Rezasi and Zskarisie, 2011d & 0,213 & 0,250 & 0,062 & $-0,276$ & 0,702 & 0,854 & 0,393 \\
\hline Karaca and Karay, 2017 & 0,471 & 0,318 & 0,101 & $-0,153$ & 1,095 & 1,490 & 0,139 \\
\hline Mokaram A Shakatst, et al. & 1,273 & 0,308 & 0,094 & 0,673 & 1,873 & 4,158 & 0,000 \\
\hline A Mazzi, 2018 & 1,252 & 0,168 & 0,028 & 0,923 & 1,581 & 7,448 & 0,000 \\
\hline Kim et al., 2016 & 0,303 & 0,124 & 0,015 & 0,080 & 0,546 & 2,444 & 0,015 \\
\hline Karay and Kokssi, 2009 & 0,415 & 0.211 & 0,045 & 0,001 & 0,829 & 1,963 & 0,050 \\
\hline Karatas and $O_{z c a n}, 2010$ & 1,664 & 0,357 & 0,128 & 0,964 & 2,364 & 4,658 & 0,000 \\
\hline Erdogan et al., 2009 & 0,967 & 0,281 & 0,079 & 0,415 & 1,518 & 3,436 & 0,001 \\
\hline Yargin, 2014 & 0,442 & 0,163 & 0,027 & 0,121 & 0,762 & 2,703 & 0,007 \\
\hline Kincal et al., 2016 & 0,500 & 0,316 & 0,100 & $-0,060$ & 1,179 & 1,770 & 0,077 \\
\hline Dersady and Yildrim, 2017 & 0,095 & 0,207 & 0,043 & $-0,310$ & 0,501 & 0,461 & 0,645 \\
\hline Syyar and Hamurou, 2018 & 0,141 & 0,227 & 0,052 & $-0,305$ & 0,587 & 0,620 & 0,536 \\
\hline Varzaneh and Bưrariocie, 2015 & 1,708 & 0,212 & 0,045 & 1,292 & 2,124 & 8,045 & 0,000 \\
\hline Yu-Stari Chargy, 20139 & 0,148 & 0,129 & 0,036 & $-0,224$ & 0,516 & 0,774 & 0,439 \\
\hline Yu-Sian Chang, 20136 & 0,481 & 0,191 & 0,037 & 0,096 & 0,835 & 2,411 & 0,016 \\
\hline Ulger and Imer, 2013 & 0,841 & 0,243 & 0,059 & 0,363 & 1,318 & 3,453 & 0,001 \\
\hline \multirow[t]{2}{*}{ Karata and Ozcan, 2015} & 0,638 & 0,294 & 0,087 & 0,061 & 1,215 & 2,167 & 0,030 \\
\hline & 0,631 & 0,095 & 0,009 & 0,445 & 0,818 & 6,631 & 0,000 \\
\hline
\end{tabular}

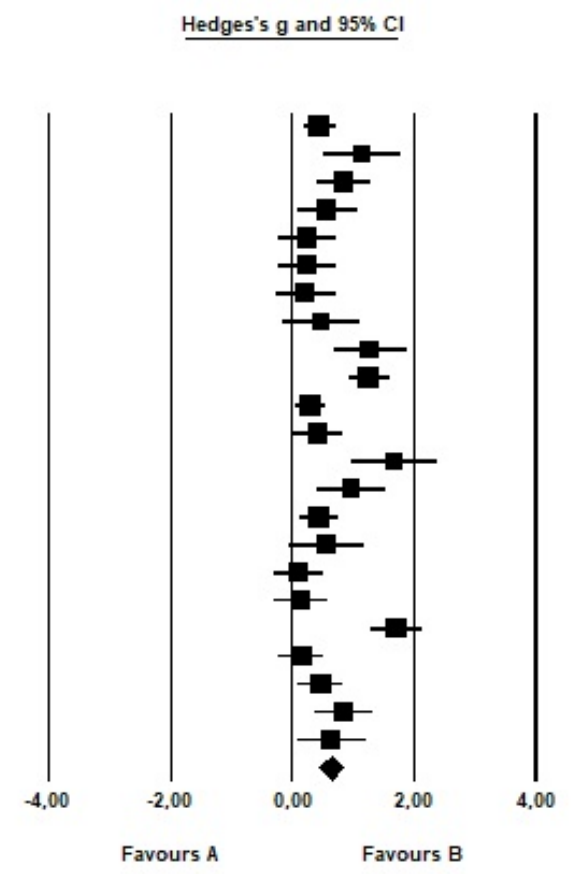

Figure 5. Forest graphic of the studies

According to forest graphic in Figure 5, the study with the largest effect size was carried out by to Varzaneh and Baharlooie (2015) and the one with the lowest effect size was conducted by Şensoy and Yıldırım (2017). When the significance of the studies' effect sizes was investigated on the basis of $95 \%$ confidence range, it was found that 15 comparisons possessed significant effect size $(p \leq .05)$ while 8 comparisons had no meaningful effect size ( $p>05)$. When the effect sizes of 19 studies (23 comparisons) were integrated on random effect model, the upper limit was calculated as 0.445 , the lower limit was 0.818 and effect size value was 0.631 at 0.095 standard error and $95 \%$ confidence interval. This value reflects a "medium" level effect size for the classification by Cohen (1988). Hence, it is rational to report that teaching strategies, methods and techniques had a medium level impact on creative thinking skills. 


\section{Moderator Analysis}

The categorical moderator analysis results based on the random effect model to explain the effect of the publication countries included in this meta-analysis on the total effect size are presented in Table 7.

Table 7.

Moderator Analysis Results for Publication Country

\begin{tabular}{|c|c|c|c|c|c|c|c|c|c|}
\hline \multirow{2}{*}{\multicolumn{2}{|c|}{ Variable }} & \multirow{2}{*}{$\mathbf{N}$} & \multirow{2}{*}{ Effect Size } & \multirow[t]{2}{*}{ Std. Error } & \multicolumn{2}{|c|}{$\begin{array}{c}\text { \%95 Confidence } \\
\text { Interval }\end{array}$} & \multicolumn{3}{|c|}{ Heterogeneity } \\
\hline & & & & & $\begin{array}{l}\text { Lower- } \\
\text { limit }\end{array}$ & $\begin{array}{l}\text { Upper- } \\
\text { limit }\end{array}$ & $\mathbf{Q}$ & df & $p$ \\
\hline \multirow{5}{*}{ 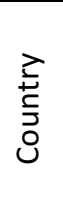 } & Turkey & 13 & 0.608 & 0.101 & 0.411 & 0.806 & & & \\
\hline & Iran & 5 & 0.602 & 0.313 & -0.011 & 1.215 & & & \\
\hline & Taiwan & 2 & 0.302 & 0.157 & -0.006 & 0.610 & & & \\
\hline & Other & 3 & 0.919 & 0.371 & 0.191 & 1.647 & & & \\
\hline & Total & 23 & 0.543 & 0.080 & 0.386 & 0.700 & 3.825 & 3 & 0.281 \\
\hline
\end{tabular}

As seen from Table 7, it was highlighted that there was no statistically significant difference between the effect sizes of the groups which were categorized based on publication countries $(Q=3.825 ; p>.05)$, which emphasized that the impact of teaching strategies, methods and techniques on creative thinking do not change for the publication country.

Table 8.

Moderator Analysis Results for Education Grade of the Study Group

\begin{tabular}{|c|c|c|c|c|c|c|c|c|c|}
\hline \multirow{2}{*}{ Variable } & & \multirow{2}{*}{$\mathbf{N}$} & \multirow{2}{*}{ Effect Size } & \multirow{2}{*}{ Std. Error } & \multicolumn{2}{|c|}{$\begin{array}{c}\text { \%95 Confidence } \\
\text { Interval }\end{array}$} & \multicolumn{3}{|c|}{ Heterogeneity } \\
\hline & & & & & $\begin{array}{c}\text { Lower- } \\
\text { limit }\end{array}$ & $\begin{array}{l}\text { Upper- } \\
\text { limit }\end{array}$ & $\mathbf{Q}$ & df & $p$ \\
\hline \multirow{5}{*}{ 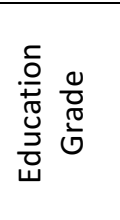 } & Secondary & 10 & 0.516 & 0.099 & 0.322 & 0.710 & & & \\
\hline & University & 6 & 0.635 & 0.177 & 0.288 & 0.982 & & & \\
\hline & High School & 3 & 1.217 & 0.279 & 0.669 & 1.765 & & & \\
\hline & Primary & 3 & 0.260 & 0.116 & 0.033 & 0.487 & & & \\
\hline & Total & 22 & 0.487 & 0.067 & 0.355 & 0.619 & 11.466 & 3 & 0.00 \\
\hline
\end{tabular}

As seen from Table 8, it depicts the categorical moderator analysis results based on random effect model to clarify the effect of the total effect size of the education grade of the study level included in this meta-analysis. Since there was only one pre-school level study (Dikici Sığırtmaç, 2016), it was eliminated from the analysis. There was a statistically significant difference between the effect sizes of the groups formed based on educational grade level $(Q=11.466 ; p>05)$. The highest effect size was observed in the researches done with high-school students (1.217) while the lowest value was in the studies with elementary school students (0.260). This result showed that the effect of teaching strategies, methods and techniques on creative thinking differed based on the education grade of the study group. Categorical moderator analysis results performed on the basis of random effect model to determine the effect of the study discipline included in this meta-analysis on the total effect size is given in Table 9. 
Table 9.

Moderator Analysis Results for the Studied Disciplines

\begin{tabular}{|c|c|c|c|c|c|c|c|c|c|}
\hline \multirow{2}{*}{\multicolumn{2}{|c|}{ Variable }} & \multirow{2}{*}{$\mathbf{N}$} & \multirow{2}{*}{ Effect Size } & \multirow{2}{*}{$\begin{array}{l}\text { Std. } \\
\text { Error }\end{array}$} & \multicolumn{2}{|c|}{$\begin{array}{c}\text { \%95 Confidence } \\
\text { Interval }\end{array}$} & \multicolumn{3}{|c|}{ Heterogeneity } \\
\hline & & & & & $\begin{array}{l}\text { Lower- } \\
\text { limit }\end{array}$ & $\begin{array}{l}\text { Upper- } \\
\text { limit }\end{array}$ & $\mathbf{Q}$ & df & $\mathbf{p}$ \\
\hline \multirow{7}{*}{$\begin{array}{l}\stackrel{0}{.} \\
\frac{.0}{\bar{O}} \\
. \frac{n}{0}\end{array}$} & Educational Sciences & 7 & 0.574 & 0.170 & 0.240 & 0.908 & & & \\
\hline & Physical Sciences & 5 & 0.399 & 0.084 & 0.235 & 0.563 & & & \\
\hline & Art Education & 5 & 0.423 & 0.126 & 0.176 & 0.670 & & & \\
\hline & Social Sciences & 2 & 0.840 & 0.287 & 0.278 & 1.402 & & & \\
\hline & Language Education & 2 & 1.462 & 0.227 & 1.016 & 1.907 & & & \\
\hline & Other & 2 & 0.896 & 0.175 & 0.554 & 1.238 & & & \\
\hline & Total & 23 & 0.562 & 0.057 & 0.450 & 0.675 & 25.289 & 5 & 0.00 \\
\hline
\end{tabular}

As seen from Table 9, it was found out that there was a statistically significant difference between the effect size of the groups formed based on study disciplines $(Q=25.289 ; p>.05)$. The highest effect size was measured in the studies on language education (1.462) while the lowest effect size was observed in the ones about physical sciences (0.399). This result proved that the effect of teaching strategies, methods and techniques on creative thinking varied for the study discipline.

Based on the random effect model, a categorical moderator analysis was executed to describe the effect of teaching method and technique included in this meta-analysis on the total effect size and the results are given in Table 10. In the moderator analysis process, applied teaching method and techniques were initially classified as active learning strategies and cognitive activation strategies. While active learning strategies category covered the studies applying a problem-based learning, narrative, cooperative learning methods, cognitive activation strategies category included brainstorming, six hat thinking technique, Van Hiele Model and Porphyrios Tree technique.

Table 10.

Moderator Analysis Results for Studied Discipline

\begin{tabular}{|c|c|c|c|c|c|c|c|c|c|}
\hline \multirow{2}{*}{ Variable } & & \multirow{2}{*}{$\mathbf{N}$} & \multirow{2}{*}{$\begin{array}{l}\text { Effect } \\
\text { Size }\end{array}$} & \multirow{2}{*}{$\begin{array}{l}\text { Std. } \\
\text { Error }\end{array}$} & \multicolumn{2}{|c|}{$\begin{array}{c}\text { \%95 Confidence } \\
\text { Interval }\end{array}$} & \multicolumn{3}{|c|}{ Heterogeneity } \\
\hline & & & & & $\begin{array}{l}\text { Lower- } \\
\text { limit }\end{array}$ & $\begin{array}{l}\text { Upper- } \\
\text { limit }\end{array}$ & $\mathbf{Q}$ & df & $\mathbf{p}$ \\
\hline \multirow{3}{*}{ 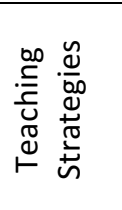 } & $\begin{array}{l}\text { Active Learning } \\
\text { Strategies }\end{array}$ & 17 & 0.559 & 0.106 & 0.352 & 0.767 & & & \\
\hline & $\begin{array}{c}\text { Cognitive Activation } \\
\text { Strategies }\end{array}$ & 6 & 0.841 & 0.201 & 0.447 & 1.235 & & & \\
\hline & Total & 23 & 0.621 & 0.094 & 0.437 & 0.804 & 1.533 & 1 & 0.216 \\
\hline
\end{tabular}

As seen from Table 10, it was figured out that there was no statistically significant difference between the effect size of the groups formed based on teaching strategies, methods and techniques $(Q=25.289 ; p>.05)$. This outcome suggests that the effect of teaching strategies, methods and techniques on creative thinking do not change for the teaching strategies, methods and techniques.

\section{Discussion, Conclusion and Implications}

The purpose of this research was to describe the effects of teaching strategies, methods and techniques on the development and improvement of creative thinking skills. Based on the results of 
the meta-analysis, it was concluded that teaching strategies, methods and techniques possessed a medium level impact on students' development and improvement of creative thinking skills. Additionally, the effect of teaching strategies, methods and techniques on creative thinking skills development exhibited no significant difference for non-traditional teaching method and technique, which meant that non-traditional strategies, methods and techniques based on students' active participation held similar ratios to develop creativity. The common assumption of studies on creativity highlights creativity is a characteristic that can be developed (Aerila \& Rönkkö, 2013; Burbiel, 2009; Robinson, 2017). Creativity is a process that enables mind to operate intuitively and demands a supportive environment with proper conditions and freedom for creative thinking (Wang, Peck \& Chern, 2010). Classrooms are the variables main supportive setting. According to Lin and Wu (2016), creativity has become a feature of teachers who ensure the permanence of students' learning with innovative and creative teaching methods. However, classroom activities are not the sole factor for development of creativity. If creative thinking was explained by just teaching methods, the effect of all teaching practices designed to promote creativity would be significant and high. For example, in their research on secondary school science class, Kanlı and Emir (2013) reported that problem-based learning was of no effect on creative thinking skill. Yang, Lee, Hong and Lin (2016) studied with secondary school science class and emphasized the impact of research-based learning on creative thinking. However, these studies that analyzed the same course, education grade and the same independent variable as the effecter on creativity underlined different findings. It is also notable to consider which components play a role in students' creative thinking processes. Various conditions such as problem-solving requirements, teachers' creativity, students' intrinsic motivation, personality and interest for the target topic, the convenience of teaching method should be taken into account. These might explain the medium level effect of teaching methods on creative thinking skills. Creativity is a multifaceted structure influenced by various factors such as individual and social opportunities. San (2003) indicated that genetics and environmental factors also influence creative intelligence and creativity skills.

Tienken (2013) stated that no country can be standardized to have more creative citizens however, students can be taught creativity-related behaviors and skills through problem-, projectand activity-based programs. The study results demonstrated that the effect of teaching strategies, methods and techniques on students' creative thinking skills was of no significant difference for study country. AlMutairi (2015) found that brainstorming technique plays a critical role on secondary school 7th grade students' creative thinking skills in Kuwait. Al Masri (2018) indicated that brainstorming technique created a meaningful difference in high-school 10th grade students' creative thinking skills. This study investigated the impacts of various applications/practices in education technologies field in Taiwan, Turkey, South Korea, Indonesia, Iran on creative thinking and, observed significant difference in favor of the experiment group (Chang, 2013; Katırcl \& Satırcl, 2010; Kim, Park, Yoo \& Kim, 2016; Shabrina \& Kuswanta, 2018; Varzaneh \& Baharlooie, 2015). When the study results with the data from different countries were reviewed, it was clearly seen that these studies concluded similar findings. The answers to "How can humans learn and how do they think?" question by the psychology are generalizable, factual and universal. Educators developed their teaching applications by integrating them with psychology so as to expand students' creativity. These developed teaching strategies, methods and techniques are applied in the same manner and with the same purpose around the world. Therefore, students will reflect similar learning outcomes regardless of the country and strategies, methods and techniques made use of. In this sense, teachers are to understand the conditions that encourage creative thinking and how students can think more efficiently to be creative (OECD, 2019). 
The study results revealed that the effect of teaching strategies, methods and techniques on students' creative thinking skills significantly varied at educational grades. The progress of children's creativity between the ages of 3 to 18 years old was looked into with long-term studies. Creative Thinking Test developed and applied by Torrance (1963, as cited in Yontar, 1993) stressed that creativity generally improved with age, but showed a decline in certain ages (3-18 years old). In this study, the highest effect was found on high-school students while the lowest effect was measured in the ones with primary school students. Jindal-Snape et al. (2013) searched the influence of creativity on students in terms of various factors and with 18 empirical studies between 2005 and 2011. The researchers reported that children's creativity test performance increased from primary 2 nd grade to 4 th grade (7-9 years old) and stabilized or decreased at 5 th grade (10 years old). In addition to this study, other researches that were included in the meta-analysis and conducted at elementary education grade, were on primary 4th or 5th grade students. Hence, the two study results supported each other's findings. Additionally, the results were in parallel with the hypothesis that signified the growing development of creativity. Different creative properties at different ages, not possessing the same creative inclinations at the same ages and certain stagnation phases might be considered to arise due to environmental factors. The emphasize countries put on thinking education, supporting creative classroom settings, teachers' creative attitudes and activities, cultures' openness to creativity might contribute to students' creative development. On the contrary, didactic teaching, decisions made for students, programs that are not relevant with real-life and applications that are not associated with structuralism and active learning-based teaching might prevent creative development.

The study results showed that the effect of teaching strategies, methods and techniques on students' creative thinking skills significantly varied for study discipline. The highest effect was found in studies on language education field while the lowest effect was calculated in studies on physical sciences field. Ghonsooly and Showqi (2012) noted that cognitive functions such as cognitive flexibility and working memory, develop in foreign language learning, which in turn influences creativity. It was reported that foreign language teaching at schools considerably increased creativity-related components such as fluency, attention, authenticity and flexibility. According to Piasecka (2018) the students in foreign language classes take the risk to coin words that they are not sure about the meanings of those words. Students might put higher mental efforts when they are not exposed to the learned foreign language in their daily lives. Therefore, language education can trigger the development of creativity. The learning process in physical sciences class might be more structured. In such classes, students make discoveries based on the provided information and instructions, which might explain the lowest effect in science field studies. On the other hand, science classes generally emphasize scientific creativity. In the scientific creative thinking process, it is expected that the generated product should not contradict with scientific facts and should be functional (Kutlu, Doğan \& Karakaya, 2010). However, creativity should not be restricted to scientific realities under specific circumstances. Hadzigeorgiou, Fokialis and Kabouropoulou (2012) stressed that it is a vital necessity to search for scientific creativity concept by integrating art and science that matches with the nature of science and general creativity concept. This might be the reason for the lowest effect in science field studies.

As a result of this study, it was concluded that teaching strategies, methods and techniques possessed a medium level effect on students' creative thinking skills. Additionally, it was revealed that the effect of teaching strategies, methods and techniques on creative thinking showed no significant difference for teaching activity type and study country. However, it was determined that 
teaching applications affected creativity for education grade and study discipline. Based on the study results above, the following recommendations are provided:

- The research is limited with the studies reviewed on ERIC, Google Scholar and TR Dizin databases between 2005 and 2019. Other studies might review international education databases such as Scopus, Taylor and Francis, Springer, HW. Wilson, Science Direct, and empirical studies might be re-evaluated within this scope. Additionally, this study only included papers and excluded thesis studies. If needed, a study including thesis studies might be designed.

- In this study, the target was to determine the effect on teaching strategies, methods and techniques on creative thinking based on activity type, study discipline and study country. Future studies might examine different variables such as sample size, measurement tool structure, and study application duration etc., and conduct analysis on studies that implement the same instrument.

- This study generally considered the studies that focused on the development of "creative thinking". Studies with teaching applications that affect dependent variables such as scientific creativity, mathematical creativity and artistic creativity might be dealt in the future.

- In this study, it was described that teaching strategies, methods and techniques had a medium level effect on students' creative thinking skills. Other studies might investigate factors such as motivation, interest, creative learning environment, teachers' attitude, and personality that impacts creativity.

- Teaching strategies, methods and techniques are among the major environmental factors that develop creative thinking. Therefore, creative thinking should be supported in education policies, and enriching the curriculum with related activities should be underlined. 


\section{TÜRKÇE SÜRÜM}

\section{Giriş}

Bireyler karşılaştıkları problem ya da çıkmazları çözmek istediğinde ya var olan çözüm yollarını denerler ya da yeni yollar oluştururlar. Bu kapsamda gündelik, teknolojik, bilimsel vb. birçok alanda yeni fikirlere, düşüncelere, ürünlere ihtiyaç duyulmaktadır. 21 yüzyılda dikkat çeken nokta özellikle eğitimde, sanatta, bilimde ezberleri bozan ve yeni akımlara öncülük eden toplumların ön sırada yer almasıdır. Bu toplumlarda inovatif düşünmenin ve inovatif kültürün yerleştiği görülmektedir. İnovatif düşünme farklı şeylerin yapılması, yeni fikirlerin/davranışların üretilmesi veya kullanılmasıdır (Damanpour \& Schneider, 2009; Reiman \& Dotger, 2008; Stenberg, 2017). İnovatif davranış ise, yeni fikirlerin üretildiği, oluşturulduğu, geliştirildiği, uygulandığı, tanıtıldığı, gerçekleştirildiği ve değiştirildiği bir süreçtir (Thurlings, Evers \& Vermeulen, 2014). Inovasyon ve yaratıclık değerli bir şey üretmek ve geliştirmek amacıyla yaratıcı süreçlerle birbirlerine bağlanırlar (Stenberg, 2017; Taylor, 2017). İnovasyon yeniliğin oluşturulmasıdır ve yaratıcı düşünmeyle ilgilidir. Ancak yaratıcılığın sadece bilim ve sanatla ilgili bir beceri olarak algılanmaması gerekir. Yaratıcılık ayrıca önemli bir yaşam becerisidir. Bu nedenle gündelik hayatta karşılaşılan büyük, küçük ya da orta ölçekli herhangi bir sorunun çözümünde dahi zihinsel çabaya ve üretime ihtiyaç vardır.

Yetenekli insanlar becerilerini kullanarak bilgi üretir ve toplumu yenilikleri anlamasına yardımcı olarak etkilerler. Bu nedenle bireylerin uygun becerileri seçmesine, edinmesine ve kullanmasına olanak tanıyan ortamların oluşturulması sağlanmalıdır (Organization for Economic Co-operation and Development, [OECD], 2015). Toplumların gittikçe karmaşıklaşan sorunlarına yaratıcı çözümler geliştirebilecek bireylerin yetiştirilmesi toplum için önemlidir. Eğitimde de yaratıcılık 21. yüzyılın önemli bir becerisi olarak kabul edilmektedir (Kupers, Lehmann-Wermser, McPherson \& van Geert, 2019; Lin \& Shih, 2016; Tan, 2000). Sungur'un (1997) belirttiği üzere "eğitimin amacı, diğer kuşakların yaptıklarını yineleyen değil yeni şeyler yapabilme yeteneği olan insanlar yaratmaktır" (p. 31). Bugün birçok kuruluş, dernek ya da ülke düşünme becerilerini geliştirmeyi önemsemekte ve programlarında yaratıcı düşünme eğitimine de yer vermektedir. Örneğin, UNICEF eğitimin öğrenci merkezli olmasını ve öğrencilerin yaratıcı düşünme becerilerinin geliştirilmesini önemli görmektedir (Chakera \& Tao, 2019). Türkiye'de uygulanmakta olan ilköğretim, ortaöğretim programlarında yaratıcılık kazanılması gereken önemli bir yaşam becerisi ve mühendislik becerisi olarak programda yerini almaktadır (Ministry of National Education [MoNE], 2020). PISA ve TIMMS gibi sınavlarda başarı sıralamasıyla dikkat çeken Singapur'un eğitim sisteminde de 21. yüzyıl becerilerine değinilmekte ve öğretim programlarında yaratıcılığın ve inovatif düşünmenin gelişimine odaklanılmaktadır (Ministry of Education Singapur, [MoES], 2020). Öğrencilerin yaratıcı düşünme becerilerini geliştirmek için birçok öğretim uygulaması üzerinde çalışılmaktadır. Bu araştırmada da farkı disiplin, ülke ve yaş kademesinde uygulanan öğretim yöntem, teknik ya da stratejilerinin yaratıcı düşünme üzerindeki etkisinin incelenmesi amaçlanmıştır.

\section{Yaratıcılık ve Yaratıcı Düşünme}

Yaratıcılık yeni, farklı, orijinal, değerli, benzersiz fikirlerin/eylemlerin oluşturulmasıdır. Yaratıcılık sorunlara çözüm yollarının üretildiği, daha önce aralarında bağlantı kurulmamış durumlardan özgün sentezlemelerin yapıldığı, merak ve keşif isteği gibi duygulardan beslenen bilişsel bir yetenektir (Craft, 2001; Csikszentmihalyi, 1997; Forrester, 2008; Harris, 1998, Keun \& Hunt, 2006; San, 2003). Yaratııılık problemlerin yaratıcı düşünerek çözülmesi sürecidir (Cash, Rae, Steel \& Winkler, 2012). Yaratıcı düşünme, "yeniliğin ve değişimin kaynağı ve geleceğin uzantısıdır" (Yıldırım, 2002, p. 7). Torrance (1965) yaratıcı düşünmeyi zorlukları, problemleri, bilgi boşluklarını, eksik unsurları, çarpık bir şeyi algılamak, tahminde bulunmak, eksikler hakkında hipotezler oluşturmak, tahmin ve hipotezleri değerlendirmek, test etmek, gözden geçirmek, yeniden test etmek ve sonuçları iletmek olarak tanımlamaktadır. Robinson (2017) yaratıcılığı değeri olan orijinal fikirleri ortaya çıkarma olarak 
ifade etmekte ve yaratıcılığın inovasyon ve hayal gücü ile ilişkisini belirtmektedir. Ayrıca herkesin doğuştan yaratıcılık potansiyeline sahip olduğunu, toplumsal yaratıcılığın herkesi kapsaması gerektiğini ve yaratıcılığın sadece sanatla (müzik, dans, resim) değil her çalışma alanında (fen, matematik vb.) ortaya çıkabileceğini vurgulamaktadır. Lipman’a (1995) göre, öğrencilerin üst düzey düşünür olabilmeleri için yaratıcı düşünmeleri gerekmektedir. Onların icat etmeyi de içeren yaratıcı düşünceleri sanatsal ve bilimsel sorgulama süreçlerinden oluşmaktadır. Tanımlardan ve açıklamalardan anlaşılacağı üzere yaratıcılık yenilikleri hayal etme, tasarlama ve oluşturmayla ilgilidir. Insanlar doğuştan getirdikleri bu yetenekleriyle problemlerini çözebilmekte ve böylece geleceklerini şekillendirebilmektedir.

Yaratıcı düşünmeyi tek bir beceri olarak görmek doğru değildir. Yaratıcılığa bakmanın ve düşünmenin birçok yolu vardır. Örneğin, tek bir fikir iki çelişkili referans çerçevesinde tutulduğunda yaratıcılık ortaya çıkabilir. Tek fikir hayattır; çelişkili iki çerçeve referans ise madde ve zihindir (Low, 2006). Yaratıcı düşünme çok boyutlu olup birden fazla alt bilişsel yeterlik/özellik içerir. Hayal etme, esneklik, akıcılık, orijinallik, duyarlıık, sentez gibi bilişsel yeterlikler yaratıcı düşünmenin unsurları arasındadır (Allen \& Thomas, 2011; Chang, Li, Chen \& Chiu, 2015; Lin \& Wu, 2016; Perry \& Karpova, 2017; Torrance, 1965; Yarbrough, 2016). Torrance (2018) tarafından yaratıcı düşünme becerilerinin tespit edilmesi amacıyla geliştirilen test "akıcılık, orijinallik, ayrıntılama, başlıkların soyutluğu, erken kapamaya direnç" şeklinde beş alt yapıdan oluşmaktadır. Gilford (1950) tarafından geliştirilen yaratıcı düşünme testinde yaratıcılık "orijinallik, akııılık, esneklik ve ayrıntılama" boyutlarıyla açıklanmaktadır (as cited in Varzaneh \& Baharlooie, 2015). Her alt yapı yaratıcı düşünmenin boyutlarından biridir ve tek tek ölçülebilecekleri gibi birlikte ölçülerek yaratıcılığı açıklayabilmektedir. Bu durum araştırmacıların, eğitimcilerin neyi geliştirmek ve ölçmek istediğine bağı olarak değişmektedir. Bu araştırmada analize dahil edilen çalışmalarda yaratıcılığın farklı boyutlarının incelenerek toplam yaratıcılık puanlarının oluşturulduğu ve yaratıcı düşünme becerisinin yorumlandığı görülmektedir.

Yaratııı kapasite çok yönlüdür ve çeşitli değişkenlerden etkilenerek gelişebilmektedir. Yaratııılığı teşvik etmenin en az yaratıcılığın boyutları kadar yolunun olduğu varsayılabilir (Sak \& Oz, 2010). Bugüne kadar yaratıcı düşünce süreçlerini geliştirmek için çeşitli eğitim programları önerilmiş (Craft, 2001); bir dizi yaklaşım ve teknik yaratıcılığın çeşitli yönlerini desteklemek için kullanılmıştır (Sak \& $\mathrm{Oz}, 2010)$. Jeffrey ve Craft (2004), öğrencilerin kendilerini öğretmenlerinin öğretim yaklaşımına göre şekillendirdiklerini, yaratıcılığın öğretmenlerin yaratıcı öğretimlerinden etkilendiğini ifade etmektedir. Sternberg (2003), yaratıcılığın farklı türlerde olabileceğini, öğretmenlerin her türlü yaratıcılı̆̆ı ödüllendirmesi gerektiğini ve öğrencilerinin yaratıcılıklarını arttıracak kararlar verilmesini önemli görmektedir. Baghetto, Kaufman ve Baer (2015), öğrencilerin belli bir alanda yaratıcı düşüncelerini geliştirmek için öğretmenlerin bu alan hakkında gerçek içerik sağlamasını ve aynı zamanda alana özgü bilişsel beceriler geliştirmelerini önemli bulmaktadır. Wu ve Lin (2001) ise, yaratıcı düşünme öğretiminin çeşitlilik içermesine, aktif öğretim stratejilerine dayanmasına ve öğrenci odaklı olmasına vurgu yapmaktadır (as cited in $\mathrm{Ku} \& \mathrm{Kuo}, 2014$ ). Araştırmacılar yaratıcı düşünmenin gelişimini destekleyecek öğretim stratejileri üzerinde çalışmış ve önerilerde bulunmuşlardır:

- Bono (1999), çok yönlü düşünebilmeyi kazandırmak amacıyla tasarladığı altı şapkalı düşünme tekniğiyle yaratıcılığın geliştirilebildiğini ileri sürmektedir.

- Torrance $(1972,1998$ as cited in Shaughnessy, 1998) problem çözme, yaratıcı problem çözme, yaratıcı araştırma, medya ve okuma eğitimi, görsel sanatlar, yaratıcı drama, sosyodrama, rol oynama ve kendi kendine öğrenme gibi stratejilerin yaratıcı düşünmeyi desteklediğini belirtmektedir.

- Gilbert (1992) yaratıcıllı̆ın geliştirilmesi için ilişkilendirme, hayal gücü, beyin fırtınası, organizasyon, analoji ve benzetme ve yeniden kavrama uygulamalarını içeren altı yol önermektedir. 
- Horng, Hong, Chanlin, Chang ve Chu (2005) öğrenci merkezli faaliyetler, öğretim içeriği ile gerçek yaşam arasında bağlantı kurma, açık uçlu sorular sorma, teknoloji ve multimedya kullanma, gerçek yaşam deneyimlerinin yaratıcı düşünmeyi geliştirdiğinden bahsetmektedirler.

- Kind ve Kind (2007) yaratıcılı̆̆ı teşvik etmede açık sorgulama, yaratıcı problem çözme, yaratıcı yazma, metafor ve analoji oluşturma şeklinde uygulamaların kullanılabileceğini belirtmektedir.

- Buzan ve Buzan (2011), zihin haritası tekniğinin kullanılmasıyla yaratıcı düşünmenin gelişimine katkı sağlandığını söylemektedir.

- Kampylis ve Berki (2014) tüm derslerde yaratıcı düşünmenin geliştirilmesini, öğrenme ortamlarının yaratıcı düşünmeyi sağlayıcı şekilde düzenlenmesini, açık uçlu soruların sorulmasını, otantik öğrenme deneyimlerinin kazanılmasını, iş birliği yapılmasını, eğitim teknolojisinden etkili şekilde yararlanılmasını, hata yapma ve risk almayı sağlayıcı etkinliklerin hazırlanmasını yaratıcı düşünme açısından gerekli görmektedir.

Yaratıcı düşünme becerilerinin gelişimi için önerilen öğretim uygulamaları incelendiğinde öğrenci merkezli oldukları, öğrencinin zihinsel olarak aktif katılımlarını sağladıkları, sorgulamayı önemli gördükleri hissedilmektedir. OECD (2016) öğretim uygulamalarını "aktif öğrenme stratejileri, bilişsel etkinleştirme stratejileri ve öğretmen güdümlü öğretim stratejileri" şeklinde sınıflandırmıştır. Öğretmen güdümlü öğretim stratejileri dersin ağırı̆ğının öğretmende olduğu stratejilerdir. Bu süreçte ders hedeflerinin açıklanması, önceki derslerin özetinin verilmesi, gerçeklere dayalı soruların sorulması söz konusudur. Aktif öğrenme stratejileri öğrencilerin kendi öğrenmelerinden sorumlu oldukları, tartışma, grup çalışması, iş birliği, bilgi ve iletişim teknolojilerinin kullanılması ve bireysel öğrenme ortamlarının geliştirilmesini kapsamaktadır (OECD, 2016). Bilişsel etkinleştirme stratejileri motivasyon, eleştirel düşünme, problem çözme ve karar verme gibi üst düzey düşünme becerilerinin doğrudan geliştirilmesini sağlayan öğretim stratejilerini içermektedir (OECD, 2016). Bu araştırmada yaratıcı düşünmeyi geliştirmeyi amaçlayan öğretim uygulamaları öğretmen merkezli olarak yürütülmediğinden aktif öğrenme stratejileri ve bilişsel etkinleştirme stratejileri bağlamında gruplanmıştır. Örneğin araştırmada Kim, Park, Yoo ve Kim'in (2016) "tablet temelli etkileşimli sınıf" oluşturmaya dayalı öğretim uygulaması aktif öğrenme stratejileri kapsamında; Ülger ve İmer'in (2013) "probleme dayalı öğrenme" uygulamaları ise bilişsel etkinleştirme stratejileri olarak değerlendirilmiştir.

Sternberg (2006), yaratıcılığın "entelektüel yetenekler, bilgi, düşünme tarzları, kişilik, motivasyon ve çevre" olmak üzere birbiriyle ilişkili altı kaynaktan etkilendiğini ileri sürmektedir. Araştırmacılar yaratıcı düşünmeyi etkileyen yol ve yöntemler üzerinde çalışmaya devam etmektedirler. İlgili alan yazın tarandığında Türkiye, Amerika, İngiltere, Malezya, İran, İspanya, Meksika vb. dünyanın hemen hemen her ülkesinde yaratıcılığın incelendiği çalışmalar görülmektedir (Gocłowsko \& Crisp, 2013; Lin \& Wu, 2016; Marušić \& Sliško, 2014; Mokaram, Al- Shabatat, Fong \& Abdallah, 2011; Rábanos \& Torres, 2012; Rezaei \& Zakariaie, 2011; Wojciechowski \& Ernst, 2018; Yiğit \& Erdoğan, 2008). Bu araştırmalar fen bilimleri, İngilizce, görsel sanat, eğitim teknolojileri gibi çok çeşitli disiplinlerde ve farklı eğitim kademelerinde yürütülmüştür (Al-Masri, 2008; Chang, 2013; Koray \& Köksal, 2009; Ülger \& İmer, 2013). Araştırmalarda probleme dayalı öğrenme, beyin fırtınası, çevrimiçi problem çözme, altı şapkalı düşünme tekniği vb. öğretim uygulamalarının ayrı ayrı yaratıcı düşünme üzerindeki etkileri incelenmeye çalışılmıştır (Al-Masri, 2008; Chang, 2013; Yaman \& Yalçın, 2005; Ziadat \& Al Ziyadat, 2016). Örneğin, Şensoy ve Yıldırım'ın (2017) üniversite öğrencileriyle gerçekleştirdikleri çalışmalarında araştırma-soruşturma temelli Öğretim Teknolojileri ve Materyal Geliştirme dersinin yaratıcı düşünme üzerinde etkisinin olmadığı sonucuna ulaşılmıştır. Sayan ve Hamurcu'nun (2018) fen bilimleri dersinde geliştirilen materyaller yaratıcı düşünme bağlamında deney grubu lehine anlamlı farklılık oluşturmamıştır. Bu araştırmaya konu olan diğer araştırmalar incelendiğinde ise aktif öğrenme ve bilişsel etkinleştirme stratejileriyle yürütülen derslerde deney grubu lehine anlamlı farklılıklar gözlenmiştir. Araştırmalarda sadece bir öğretim yönteminin yaratıcılık üzerindeki etkisi incelenmiş ve görüldüğü üzere yaratıcılığın gelişimini etkileyen ve etkilemeyen çalışmalara 
rastlanmıştır. Buna göre, öğretim uygulamalarının yaratıcılığın gelişimini destekleme gücü nedir? illgili alanyazında öğretim yöntem, teknik ve stratejilerinin yaratıcı düşünme üzerindeki bütüncül etkisini belirlemeye yönelik araştırmaya rastlanmamıştır. Bu araştırmanın amacı da öğretim uygulamalarının yaratıcı düşünmeye etkisini ortaya çıkarmaktır. Böylece, öğretim uygulamalarının yaratıcılık üzerindeki ortak etkisinin ve yaratıcılığı açıklama gücünün belirleneceğine inanılmıştır. Araştırmada aşağıdaki sorulara cevap aranmıştır:

- Öğretim strateji, yöntem ve tekniklerinin yaratıcı düşünme becerisi üzerindeki etkileri nedir?

- Yaratıcı düşünme becerisi kullanılan öğretim strateji-yöntem ve teknikleri, araştırmanın yapıldığı ülke, çalışılan disiplin ve eğitim kademesi bağlamında anlamlı farklılık göstermekte midir?

\section{Yöntem}

Öğretim strateji, yöntem ve tekniklerinin yaratıcı düşünmeye etkisinin belirlenmesini amaçlayan bu çalışmada meta-analiz yöntemi kullanılmışır. "Meta analiz yöntemi bir konu, tema ya da çalışma alanı hakkındaki benzer çalışmaların belirli ölçütler altında gruplanıp, bu çalışmalara ait nicel bulguların birleştirilerek yorumlanmasıdır" (Dinçer, 2014, p. 4). Meta analiz yönteminde tek bir araştırmadan elde edilen sonuçların aksine çoklu çalışmalardaki sonuçlar vurgulanır (Shelby \& Vaske, 2008) ve daha yüksek sonuçlara ulaşlır (Büyüköztürk, Kılıç Çakmak, Akgün, Karadeniz \& Demirel, 2014). Bu araştırmada da öğretim strateji, yöntem ve tekniklerinin yaratıcı düşünme üzerindeki etkisi ya da yaratıcılığı açıklama gücü merak edildiğinden araştırmanın meta analiz yöntemiyle incelenmesi uygun görülmüştür.

\section{Verilerin Toplanması}

Araştırmanın sorularına cevap bulabilmek için öğretim strateji, yöntem ve tekniklerinin yaratıcı düşünmeye etkisini inceleyen 2005-2019 yılları arasındaki ulusal ve uluslararası alandaki yayınlar taranmıştır. Ulusal ve uluslararası çalışmalara kolaylıkla ulaşabilmeyi sağlamaları nedeniyle ERIC, Google Scholar ve TR Dizin (ULAKBIM) olmak üzere üç veri tabanından yararlanılmıştır. Makaleler "yaratıcı düşünme", "yaratıcılık", "creative thinking" ve "creativity" anahtar kelimelerinin Ingilizce ve Türkçe formları kullanılarak taranmıştır. Araştırmaya 2005 yılından itibaren başlanmasının nedeni ise Türkiye'de ilköğretim öğretim programlarındaki felsefe ve öğretim anlayışındaki değişikliklerdir. Veri tabanlarındaki ilk tarama, araştırmacılar tarafından 25 Aralık 2018 tarihinde başlamış ve 25-30 Mayıs 2019 tarihleri arasında tekrar taranarak sonlandırılmıştır.

\section{Dâhil Edilme Ölçütleri}

Veri tabanlarına (ERIC, Google Scholar, TR Dizin) ilgili anahtar sözcükler girildikten sonra incelenmek üzere 133 makale tespit edilmiştir. Ulaşılan bu makalelerin çalışmaya dâhil edilebilmesi için aşağıdaki ölçütler dikkate alınmıştır:

a. Çalışmanın Yöntemi: Bu araştırma kapsamında öğretim uygulamalarının yaratıcı düşünme becerisine etkisinin incelendiği deneysel ya da yarı deneysel çalışmalar yer almıştır.

b. Çalışmanın Yayın Türü: Kongrede sunulmak üzere tam metni ya da özeti basılmış bildiriler ve tezler çalışma kapsamının dışında tutulmuştur. Bu araştırma kapsamına sadece hakemli dergilerde yayınlanan makaleler dâhil edilmiştir.

c. Örneklem Özelliği: Deneysel ya da yarı deneysel çalışmalarda en az iki grup şartı aranmış ve deneysel ve kontrol gruplu çalışmalar araştırmaya dâhil edilmiştir.

d. Karşılaştırma: Deney ve kontrol gruplarının karşılaştırıldığı çalışmalar araştırmaya dâhil edilmiştir.

e. Veri Analizi: Araştırmaya parametrik testlerin kullanıldığı çalışmalar dahil edilmiştir. 
f. Yaratıcı Düşünme Toplam Puanı: Yaratıcı düşünme becerisi kendi içinde farklı alt boyutlarıyla ölçülebilen bir beceridir. Araştırmalarda farkı boyutların incelenmesi mümkündür. Bu araştırmaya ise öğretim uygulamalarının yaratıcı düşünme toplam değerine etkisinin analiz edildiği çalışmalar dâhil edilmiştir.

g. Veri Toplama Aracının Yapısı: Yaratııılığı ölçme şekli açısından benzerlik gösteren araçlar araştırma kapsamına alınmıştır. Ölçme aracı hakkında açıklayıcı bilginin verilmediği çalışmalar elenmiştir.

h. Nicel Veri: Meta-analiz sürecinde standartlaştırılmış etki büyüklüğünü hesaplayabilmek için ( $N$, $\mathrm{X}, \mathrm{SS}, \mathrm{F}, \mathrm{P}, \mathrm{t} . . . \mathrm{vb}$.) değerlere sahip olan ya da etki büyüklüğünün hesaplanabilmesine olanak veren verilere sahip çalışmalar araştırmaya dahil edilmiştir. 21 makale araştırmanın örneklemini oluşturmuştur. Analize dahil edilme sürecine ilişkin akış şeması şekil 1'de verilmiştir.

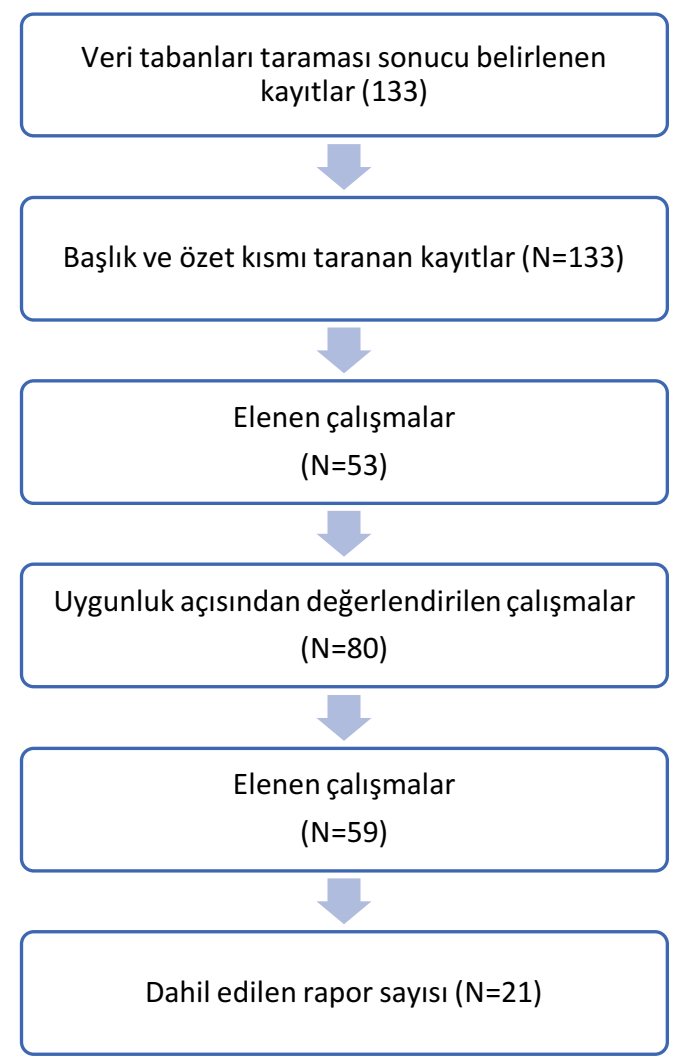

33 çalışma tek gruplu yarı deneyse/ldeneysel desende desenlendiği için; 10 çalışma nitel araştırmaya göre desenlendiği için;

9 çalışma bağımlı değişkenin farklı olması nedeniyle

1 çalıșma eș kopya nedeniyle elenmiștir.

30 çalışma non-parametrik test kullanıldığı için; 18 çalışma yaratıcı düşünme toplam puan raporlanmadığı için,

9 çalışma ölçme aracının yapısı farklı olduğu için, 1 çalışm a etki büyüklüğü için gerekli verilerin raporlanmadığı için;

1 çalışma raporlanan istatiksel değerlerde tutarsızlık bulunduğu için elenmiştir.

Şekil 1. Analize dahil edilme sürecine ilişkin akış şeması

\section{Verilerin Kodlanması}

Araştırma kapsamına alınacak çalışmalar ilgili ölçütlere göre belirlenmiş ve kodlama aşamasına geçilmiştir. Kodlama işleminde (1) Çalışma no, (2) Veri tabanı, (3) Yazar sayısı, (4) Çalışmanın yapıldığı ülke, (5) Çalışmanın yılı, (6) Akademik düzey, (7) Akademik derece/bölüm, (8) Çalışılan disiplin, (9) Bağımsız değişken, (10) Veri toplama aracı, (11) Veri analizi ve (12) N, X, SS, F, P, t...vb istatistik değerleri Microsoft Excel dosyasına girilmiştir. Bu çalışmalara ait özellikler Tablo 1'de verilmiştir. 
Sevda Dolapçıŏlu, Burcu Gürkan - Uluslararası Eğitim Programları ve Öğretim Çalışmaları Dergisi, 10(1), 2020, 149-188

Tablo 1.

Meta Analize Dahil Edilen Araştırmalara Ilişkin Demografik Özellikler

\begin{tabular}{|c|c|c|c|c|c|c|c|c|c|}
\hline No & Yazar & YII & $\begin{array}{c}\text { Karşılaştırma } \\
\text { sayısı }\end{array}$ & Ülke & Veri toplama aracı & Çalışılan disiplin & $\begin{array}{l}\text { Öğrenim } \\
\text { kademesi }\end{array}$ & $\begin{array}{l}\text { Öğretim } \\
\text { stratejileri }\end{array}$ & $\begin{array}{l}\text { Örneklem sayısı } \\
\text { (Deney+Kontrol) }\end{array}$ \\
\hline 1 & Yaman ve Yalçın & 2005 & 1 & Türkiye & TYDT & Fen Bilimleri & Üniversite & Aktif & $105+115$ \\
\hline 2 & Yiğit ve Erdoğan & 2008 & 1 & Türkiye & TYDT & Sosyal Bilgiler & Ortaokul & Aktif & $21+21$ \\
\hline 3 & $\begin{array}{l}\text { Erdoğan, Akkaya ve Çelebi } \\
\text { Akkaya }\end{array}$ & 2009 & 1 & Türkiye & TYDT & Matematik & Ortaokul & Bilişsel & $27+28$ \\
\hline 4 & Koray ve Köksal & 2009 & 1 & Türkiye & TYDT & Fen Bilimleri & Üniversite & Bilişsel & $44+46$ \\
\hline 5 & Karataş ve Özcan & 2010 & 1 & Türkiye & TYDT & Eğitim Bilimleri & Ortaokul & Bilişsel & $21+20$ \\
\hline 6 & $\begin{array}{l}\text { Mokaram, Al-Shabatat, } \\
\text { Fong ve Abdallah }\end{array}$ & 2011 & 1 & Malezya & TYDT & Eğitim Bilimleri & Üniversite & Aktif & $25+25$ \\
\hline 7 & Rezaei ve Zakariaie & 2011 & 4 & İran & TYDT & Sanat Eğitimi & Ortaokul & Aktif & $32+31$ \\
\hline 8 & Chang & 2013 & 2 & Tayvan & Yaratıcı Düşünme Testi & Eğitim Bilimleri & ilkokul & Aktif & $57+54$ \\
\hline 9 & Ülger ve İmer & 2013 & 1 & Türkiye & TYDT & Sanat Eğitimi & Ortaokul & Aktif & $36+36$ \\
\hline 10 & Yangın & 2014 & 1 & Türkiye & TYDT & $\begin{array}{l}\text { Fen Bilimleri } \\
\text { (Biyoloji) }\end{array}$ & Üniversite & Bilişsel & $74+78$ \\
\hline 11 & AlMutairi & 2015 & 1 & Kuveyt & TYDT & Düşünme Eğitimi & Ortaokul & Bilişsel & $47+51$ \\
\hline 12 & Karataş ve Özcan & 2015 & 1 & Türkiye & TYDT & Eğitim Bilimleri & Üniversite & Aktif & $24+23$ \\
\hline 13 & Varzaneh ve Baharlooie & 2015 & 1 & İran & $\begin{array}{l}\text { Gilford Yaratıcı } \\
\text { Düşünme Ölçeği }\end{array}$ & $\begin{array}{l}\text { Dil Eğitimi } \\
\text { (İngilizce) }\end{array}$ & Lise & Aktif & $60+60$ \\
\hline 14 & Ziadat ve Al Ziayadat & 2015 & 1 & Ürdün & TYDT & $\begin{array}{l}\text { Dil Eğitimi } \\
\text { (Arapça) }\end{array}$ & Ortaokul & Bilişsel & $27+32$ \\
\hline 15 & Dikici Sığırtmaç & 2016 & 1 & Türkiye & TYDT & Satranç Eğitimi & Okul Öncesi & Aktif & $41+46$ \\
\hline 16 & Kıncal, Avcu ve Kartal & 2016 & 1 & Türkiye & TYDT & $\begin{array}{c}\text { Sosyal Bilgiler } \\
\text { (Coğrafya) }\end{array}$ & Lise & Aktif & $20+20$ \\
\hline 17 & Kim, Park, Yoo ve Kim & 2016 & 1 & $\begin{array}{l}\text { Güney } \\
\text { Kore }\end{array}$ & TYDT & Eğitim Bilimleri & Ortaokul & Aktif & $137+125$ \\
\hline 18 & Karaca ve Koray & 2017 & 1 & Türkiye & TYDT & Fen Bilimleri & Ortaokul & Bilişsel & $19+20$ \\
\hline 19 & Şensoy ve Yıldırım & 2017 & 1 & Türkiye & TYDT & Eğitim Bilimleri & Üniversite & Aktif & $45+47$ \\
\hline 20 & Al Masri & 2018 & 1 & Ürdün & TYDT & $\begin{array}{l}\text { Dil Eğitimi } \\
\text { (İngilizce) }\end{array}$ & Lise & Bilişsel & $84+84$ \\
\hline 21 & Sayan ve Hamurcu & 2018 & 1 & Türkiye & TYDT & Fen Bilimleri & İlkokul & Aktif & $38+38$ \\
\hline
\end{tabular}




\section{Verilerin Analizi}

\section{iş̧em}

Meta-analiz sürecinde araştırmaya dahil edilen çalışmaların etki büyüklükleri hesaplanmıştır. Etki büyüklükleri Cohen d, Hedge's g ve Glass g değeri üzerinden hesaplanabilmektedir (Akbaş, Atalan Ergin \& Tatlı, 2019). Bu araştırmada etki büyüklükleri Hedge's g değeri üzerinden hesaplanmıştır. İstatiksel analizlerin anlamlıık düzeyi .05 olarak belirlenmiştir. Çalışmaların etki büyüklüklerinin yorumlanmasında aşağıdaki sınıflandırma kullanıımıştır (Cohen, 1988):

$$
\begin{array}{ll}
0.20 \leq \text { etki katsayısı }<0.50 & \text { küçük düzeyde } \\
0.50 \leq \text { etki katksayısı }<0.80 & \text { orta düzeyde } \\
0.80 \leq \text { etki katkısayısı } & \text { geniş düzeyde }
\end{array}
$$

Genel etki büyüklüğünün hangi modele göre (sabit, rastgele) hesaplanacağının belirlenmesi için heterojenlik testi yapılmıştır. Sabit etki modelinde çalışmaların evren büyüklüklerinin aynı olduğu ve standart sapmalarının sıfıra eşit olduğu kabul edilirken, rastgele etkiler modelinde bireysel evren büyüklüklerinin farklı olduğu ve standart sapmanın sıfıra eşit olmadığı kabul edilir. Heterojenlik testi sonucunda bireysel çalışma sonuçları homojen çıkıyorsa sabit etki modeli, heterojen çıkıyorsa rastgele etki modeli kullanılmaktadır (Dinçer, 2014). Bu bağlamda araştırmada heterojenlik testi sonucunda elde edilen $p$ değerinin anlamlı olması ve $Q$ değerinin $X 2$ tablosundaki serbestlik derecesine karşılık gelen değerden büyük olması gibi nedenlerle rastgele etkiler modeli kullanılmıştır.

Çalışmada hesaplanan genel etki büyüklüğüne etkisinin olabileceği üç değişken belirlenmiştir. Bunlar çalışmaların "yapıldığı ülke, çalışma grubunun öğrenim kademesi ve çalışılan disiplin"dir. Genel etki büyüklügünün belirlenen değişkenlere göre anlamlı bir farklılık gösterip göstermediğinin tespiti amacıyla rastgele etkiler modelinde kategorik moderatör analizi yapılmıştır. Bu araştırmada metaanaliz sürecinde Comprehensive Meta Analysis (CMA) programı kullanılmıştır.

\section{Yayın Yanlıığı}

Yayın yanlılığı meta-analiz sonuçlarını etkileyen en önemli faktörlerden biridir. Yayın yanlılığına, sadece belirli bir sonuca odaklanarak ya da sınırlı bir tarama ile elde edilen çalışmaların meta-analize dahil edilmesi neden olabilir (Dinçer, 2014). Bu bağlamda araştırmada çeşitli veri tabanlarında tarama yapıımış ve konuya ilişkin tüm çalışmalara ulaşılmaya çalışılmışır. Ulaşılan çalışmaların elenmesi amacıyla ölçütlerin belirlenmesi sürecinde, daha önce meta-analiz çalışmaları yürütülen bir uzmandan görüş alınmıştır. Meta-analize dahil edilen çalışmaların yayın yanlılığına neden olup olmadığının test edilmesi amacıyla birçok yöntemden yararlanılmaktadır. Bunlardan en çok kullanılanı huni grafiğinin incelenmesidir (Dinçer, 2014). Bu araştırmada da öncelikle huni grafiği incelenmiştir. Daha sonra yayın yanlılığı Egger'in doğrusal regresyon yöntemi kullanılarak istatistiksel olarak incelenmiştir. Egger'in doğrusal regresyon yöntemi ile yapılan incelemede $\beta 0=0$ hipotezinin anlamlı olmaması yayın yanlıığının olmadığını göstermektedir (Egger, Smith, Schneider \& Minder, 1997).

\section{Bulgular}

\section{Yayın Yanlılığı}

Çalışmaların genel etki büyüklüğünün yayın yanlılı̆ından kaynaklanıp kaynaklanmadığının belirlenmesi için öncelikle huni grafiği incelenmiştir. Bu grafikteki ortada yer alan çizgi genel etki büyüklüğünü göstermektedir. Yayın yanlılığının olmadığı durumlarda bireysel çalışmaların etki büyüklüklerinin bu çizgi etrafında olması ve huni içerisinde yer alması beklenmektedir (Dinçer, 2014). 


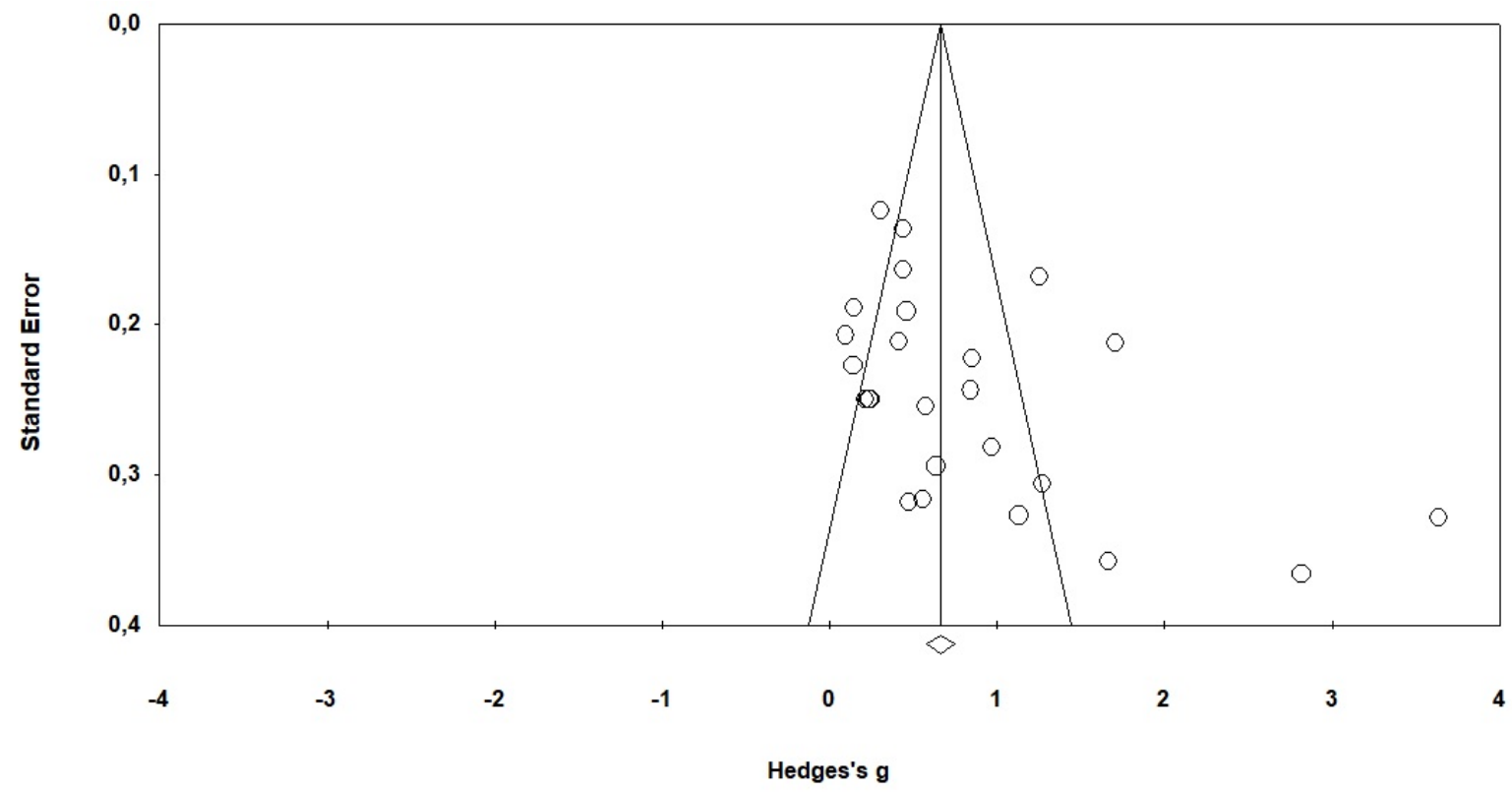

Şekil 2. Huni grafiği

Şekil 2'deki huni grafiği incelendiğinde bireysel çalışmalara ait etki büyüklüklerinin genel etki büyüklüğü etrafında asimetrik olarak dağıldığı ve bazı etki büyüklüklerinin huni çizgisi dışında yer aldığı görülmektedir. Bu durum yayın yanlılığının olabileceğini göstermektedir; ancak emin olabilmek için yayın yanlılığı istatistiklerine bakılmalıdır (Dinçer, 2014). Huni grafiğinin anlamlı olup olmadığının belirlenmesi amacıyla Egger'in kesen testi uygulanmıştır (Card, 2012). Egger'in kesen testi sonuçları Tablo 2'de verilmiştir.

Tablo 2.

Egger'in Kesen Testi Sonucu

\begin{tabular}{ccccccc}
\hline Kesen $\left(B_{0}\right)$ & Standart Hata & Alt limit & Üst limit & t- değeri & df & p-iki kuyruklu \\
\hline 4.630 & 1.844 & 0.815 & 8.556 & 2.510 & 23 & 0.01 \\
\hline
\end{tabular}

Tablo 2 incelendiğinde kesen değerinin (4.630) anlamlı olduğu $(p \leq .05)$ görülmektedir. Buna göre çalışmada yayın yanlılı̆ının olduğu söylenebilir. Çalışmalar arasında uç değerlerin yer alıp almadığının incelenmesi amacıyla analize dahil edilen çalışmalara ait orman grafiği ve her çalışma için standart artıklar incelenmiştir. 

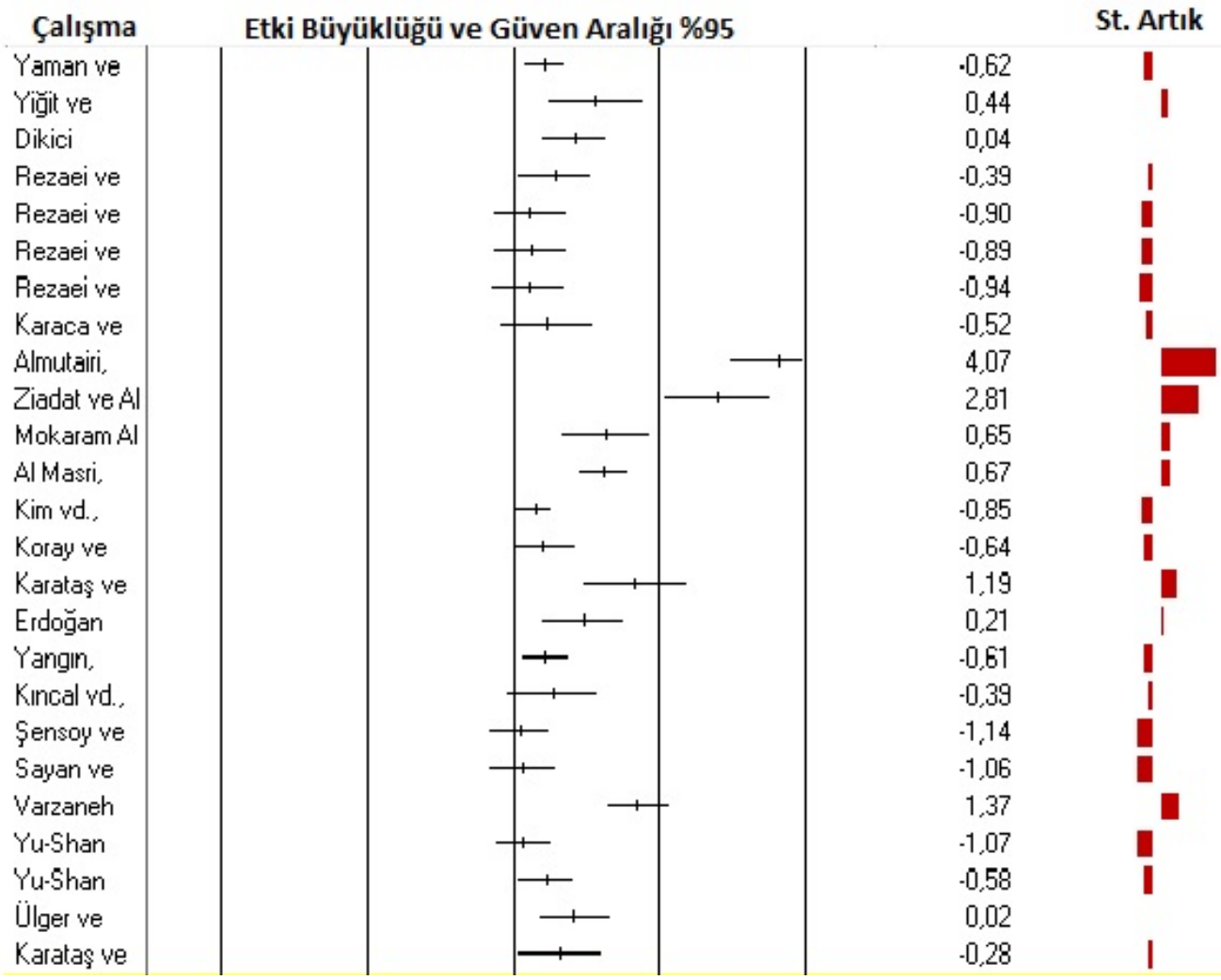

Şekil 3. Orman grafiği ve standart artıklar

Şekil 3'te görüldüğü üzere en dar güven aralığına sahip çalışmanın Kim, Park, Yoo ve Kim (2016); en geniş güven aralığına sahip olan çalışmanın ise Ziadat ve Al Ziayadat (2015) tarafından gerçekleşmiş olduğu belirlenmiştir. Orman grafiğinde iki çalışmanın 4.07 ve 2.81 standart artık değerleri ile diğer çalışmalardan ayrılarak uç değer niteliğinde olduğu görülmektedir. Uç değere sahip olabilecek çalışmalardan biri AlMutairi (2015) tarafından ortaokul öğrencileri ile yürütülmüş ve Kuveyt'te yayınlanmıştır. Diğer çalışma ise Ziadat ve Al Ziayadat (2015) tarafından ortaokul öğrencileri ile dil eğitimi alanında yapılmıştır ve Ürdün'de yayınlanmıştır. Analizden bu çalışmaların çıkarılmasının heterojenlik testi sonuçlarını nasıl etkilediği Tablo 3'te verilmiştir.

Tablo 3.

Çalışmaların Çıkarılması ile Elde Edilen Heterojenlik Testi Sonuçları

\begin{tabular}{llcccc}
\hline Çıkarılan çalışma & $\mathbf{N}$ & $\mathbf{Q}$ & $\mathbf{d f}$ & $\mathbf{X}^{\mathbf{2}}$ & $\mathbf{I}^{\mathbf{2}}$ \\
\hline 1. Hiçbiri çıkarılmadığında & 25 & 214.983 & 24 & 36.415 & 88.836 \\
2. Almutairi (2015) çıkarıldığında & 24 & 131.250 & 23 & 35.172 & 82.476 \\
3. Ziadat ve Al Ziayadat (2015) çıkarıldığında & 24 & 179.719 & 23 & 35.172 & 87.202 \\
4. Her ikisi de çıkarıldığında & 23 & 94.199 & 22 & 33.924 & 76.645 \\
\hline
\end{tabular}

Tablo 3'te görüldüğü üzere, 25 karşılaştırma ile gerçekleştirilen heterojenlik testinden elde edilen Q1=214.983 değerinin Almutairi (2015) tarafından yapılan çalışmanın çıkarıldığında Q2=131.250; Ziadat ve Al Ziayadat (2015) tarafından yapılan çalışma çıkarıldığında Q3=179.719; her iki çalışma da çıkarıldığında Q4=94.199 değerini aldığı görülmektedir.

Orman grafiği, standart artık değerler ve çalışmaların çıkarılmasının $Q$ değeri üzerindeki etkileri değerlendirildiğinde bu çalışmaların uç değer niteliğinde olduğu belirlenmiş ve analizlerden 
çıkarılması uygun görülmüştür. Kalan 19 bireysel çalışmanın (23 karşılaştırma) yayın yanlılığının olup olmadığının belirlenmesi amacıyla huni grafiği incelenmiştir.

Şekil 4. Huni grafiği

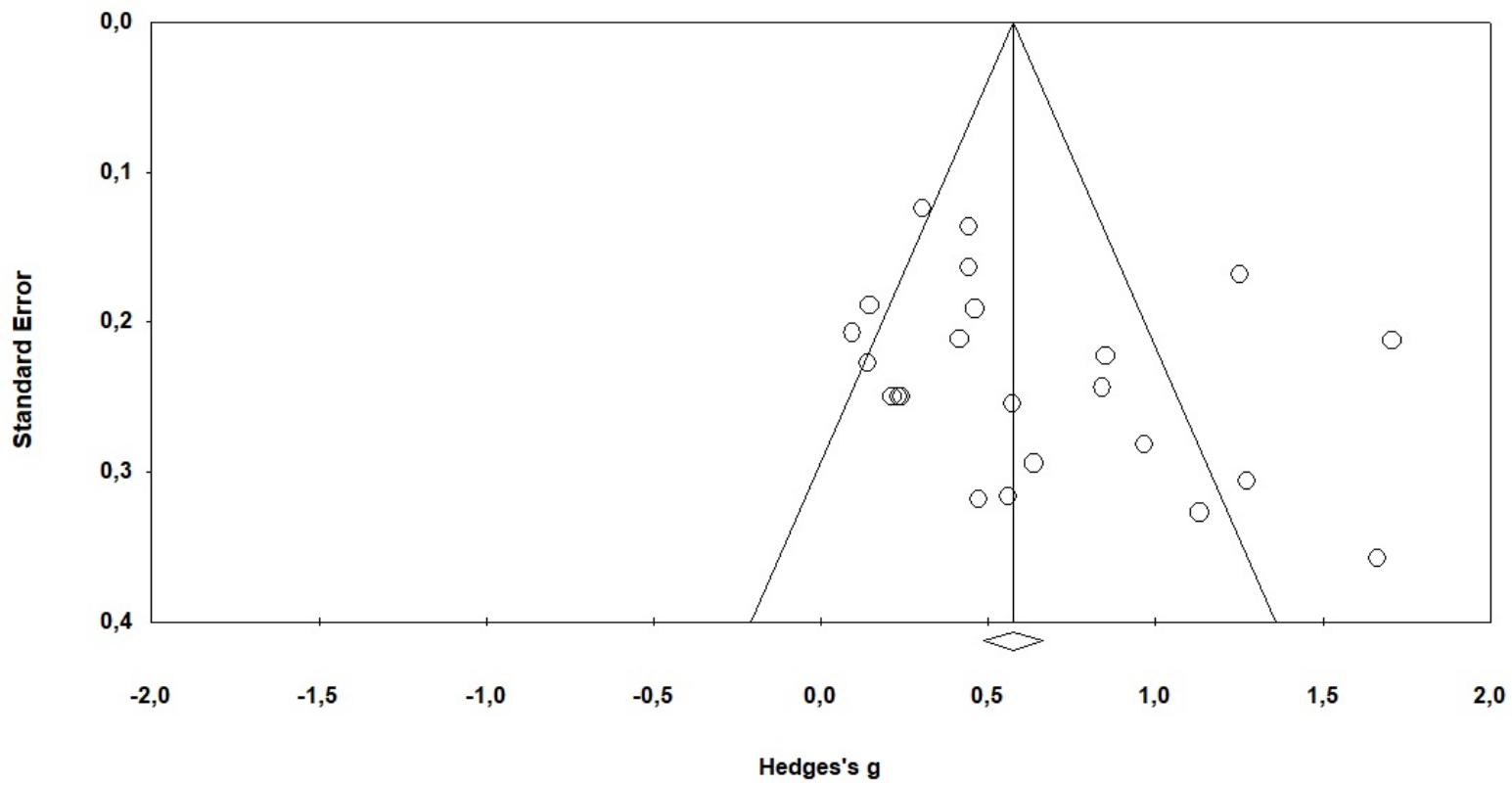

Şekil 4'teki huni grafiğinde etki büyüklüklerinin genel etki büyüklüğü etrafında asimetrik olarak dağıldığı ve bazı etki büyüklüklerinin huni çizgisi dışında yer aldığı görülmektedir. Bu durum yayın yanlılığı sorununun devam ettiğini gösterebilir. Huni grafiğinde yer alan dağılımın anlamlı olup olmadığının belirlenmesi amacıyla Egger'in kesen testi tekrar uygulanmış ve sonuçları Tablo 4 'te verilmiştir.

Tablo 4.

Egger'in Kesen Testi Sonucu

\begin{tabular}{ccccccc}
\hline Kesen $\left(B_{0}\right)$ & Standart Hata & Alt limit & Üst limit & t- değeri & $d f$ & $p$-iki kuyruklu \\
\hline 2.163 & 1.492 & -0.940 & 5.268 & 1.449 & 21 & 0.16 \\
\hline
\end{tabular}

Tablo 4'te görüldüğü gibi kesen değeri 2.163 olarak hesaplanmıştır. Hesaplanan kesen değerinin anlamlıık düzeyi incelendiğinde \%95 güven seviyesinde anlamlı olmadığı ( $p>05)$ görülmektedir. Buna göre kalan 19 bireysel çalışmada (23 karşılaştırma) yayın yanlılığının olmadığı söylenebilir.

\section{Meta-Analize Dahil Edilen Çalışmaların Özellikleri}

Araştırma kapsamında 19 bireysel çalışma değerlendirilmiş ve bu çalışmalarda toplam 23 karşılaştırma yapılmıştır. Araştırmaya dahil edilen çalışmaların tümü makale olarak yayınlanmıştır. Çalışmaların toplam örneklem büyüklüğü 1827 kişidir. Deney grubu toplam 910, kontrol grubu ise 917 kişiden oluşturulmuştur. Çalışmaların yürütüldüğü ülke, çalışma grubunun öğrenim kademesi ve çalışılan disipline yönelik bilgiler Tablo 5'te verilmiştir. 
Tablo 5.

Meta-Analize Dahil Edilen Çalışmaların Yayınlandığı Ülke, Çalışma Grubunun Öğrenim Kademesi ve Çalışılan Disipline Göre Frekans ve Yüzdeleri

\begin{tabular}{|c|c|c|c|}
\hline Değişken & & $f$ & $\%$ \\
\hline \multirow{6}{*}{ Ülke } & Türkiye & 13 & 68.42 \\
\hline & İran & 2 & 10.53 \\
\hline & Ürdün & 1 & 5.26 \\
\hline & Malezya & 1 & 5.26 \\
\hline & Tayvan & 1 & 5.26 \\
\hline & Güney Kore & 1 & 5.26 \\
\hline \multirow{7}{*}{ Çalışılan Disiplin } & Eğitim Bilimleri & 6 & 31.58 \\
\hline & Fen Bilimleri & 5 & 26.31 \\
\hline & Dil Eğitimi & 2 & 10.53 \\
\hline & Sosyal Bilgiler & 2 & 10.53 \\
\hline & Sanat Eğitimi & 2 & 10.53 \\
\hline & Matematik & 1 & 5.26 \\
\hline & Satranç Eğitimi & 1 & 5.26 \\
\hline \multirow{3}{*}{ Öğretim Kademesi } & İlköğretim & 10 & 52.63 \\
\hline & Üniversite & 6 & 31.58 \\
\hline & Ortaöğretim & 3 & 15.79 \\
\hline \multirow{2}{*}{ Öğretim Stratejileri } & Aktif Öğrenme Stratejisi & 13 & 68.42 \\
\hline & Bilişsel Etkinleştirme Stratejileri & 6 & 31.58 \\
\hline
\end{tabular}

Tablo 5'te görüldüğü gibi, araştırmaya dahil edilen çalışmaların \%68.42'si Türkiye'de, \%10.53'ü İran'da, \%5.26'sı Ürdün'de, \%5.26'sı Malezya'da, \%5.26'sı Tayvan'da, \%5.26'sı Güney Kore'de yayınlanmıştır. Çalışılan disiplin açısından \%31.58'i eğitim bilimleri, \%26.31'i fen bilimleri, \%10.53'ü dil eğitimi, \%10.53'ü sosyal bilgiler, \%10.53'ü sanat eğitimi, \%5.26'sı matematik ve \%5.26'sı satranç eğitim alanlarına yöneliktir. Çalışma grubunun öğrenim kademesi bakımından ise \%52.63'ü ilköğretim, \%31.58'i üniversite, \%15.79'u ortaöğretim düzeyindedir. Öğretim stratejileri açısından ise \%68.42'si aktif öğrenme stratejileri ve \%31.58'i bilişsel etkinleştirme stratejileri çalışmıştır.

\section{Heterojenlik Testi}

Araştırmaya dahil edilen çalışmaların sabit ve rastgele etkiler modeline göre heterojenlik değeri, ortalama etki büyüklüğü ve güven aralıkları Tablo 6'da verilmiştir.

Tablo 6.

Çalışmaların Etki Büyüklükleri ve Heterojenlik Testi Sonuçları

\begin{tabular}{|c|c|c|c|c|c|c|c|c|c|c|}
\hline \multirow{2}{*}{ Model çeşidi } & \multirow{2}{*}{$\mathbf{N}$} & \multirow{2}{*}{$\begin{array}{c}\text { Etki } \\
\text { Büyüklüğü }\end{array}$} & \multirow{2}{*}{$\begin{array}{l}\text { Std. } \\
\text { Hata }\end{array}$} & \multicolumn{2}{|c|}{$\begin{array}{c}\text { \%95 Güven } \\
\text { Aralıkları }\end{array}$} & \multirow{2}{*}{$x^{2}$} & \multicolumn{4}{|c|}{ Heterojenlik } \\
\hline & & & & $\begin{array}{c}\text { Alt } \\
\text { limit }\end{array}$ & $\begin{array}{c}\text { Alt } \\
\text { limit }\end{array}$ & & $\mathbf{Q}$ & df & p & $\mathrm{I}^{2}$ \\
\hline Sabit E. M. & 23 & 0.575 & 0.044 & 0.488 & 0.662 & 33.924 & 94.199 & 22 & 0.00 & 76.645 \\
\hline Rastgele E. M. & 23 & 0.631 & 0.095 & 0.445 & 0.818 & & & & & \\
\hline
\end{tabular}

Tablo 6'da görüldüğü gibi heterojenlik testi anlamlı $(p \leq .05)$ çıkmıştır. $Q$ değeri 22 serbestlik derecesi ile 94.199 olarak hesaplanmıştır. X2 tablosunda 22 serbestlik derecesi ve 0.05 düzeyinde kritik değer yaklaşık olarak 33.924'tür. Buna göre $Q$ değeri (94.199), kritik değerden (33.924) büyük olması, etki büyüklükleri dağıımının heterojen yapıda olduğunu göstermektedir. 12 indeksi \%76.645 değeri, çalışmaların arasındaki heterojenliğin "yüksek" düzeyde olduğunu göstermektedir. Buna göre 
araştırmanın verileri, rastgele etkiler modeline göre analiz edilmiştir. Çalışmaların rastgele etkiler modeline göre hesaplanan etki büyüklüklerine ait orman grafiği Şekil 5'te verilmiştir.

\begin{tabular}{|c|c|c|c|c|c|c|c|}
\hline \multirow[t]{2}{*}{ Study name } & \multicolumn{7}{|c|}{ Statistics for each study } \\
\hline & $\begin{array}{c}\text { Hedges's } \\
g\end{array}$ & $\begin{array}{l}\text { Standard } \\
\text { error }\end{array}$ & Variance & $\begin{array}{c}\text { Lower } \\
\text { limit }\end{array}$ & $\begin{array}{l}\text { Upper } \\
\text { limit }\end{array}$ & Z-Value & p-Value \\
\hline Yamari ve Yaç̧in, 2005a & 0,442 & 0,136 & 0,019 & 0,175 & 0,709 & 3,248 & 0,001 \\
\hline Yót ve Erdoden, 2008 & 1,133 & 0,327 & 0,107 & 0,492 & 1,774 & 3,465 & 0,001 \\
\hline Dikiai Sjbyrımsç, 2016 & 0,851 & 0,222 & 0,049 & 0,415 & 1,287 & 3,826 & 0,000 \\
\hline Rezsai ve Zsksrisie, 2011a & 0,573 & 0,254 & 0,065 & 0,075 & 1,071 & 2,256 & 0,024 \\
\hline Rezasi ve Zsksriaie, 2011b & 0.234 & 0,250 & 0,062 & $-0,256$ & 0,723 & 0,936 & 0,349 \\
\hline Rezasi ve Zsksrisie, 2011c & 0,242 & 0,250 & 0,062 & $-0,248$ & 0,731 & 0,967 & 0,334 \\
\hline Rezasi ve Zskarisie, 2011d & 0,213 & 0,250 & 0,062 & $-0,276$ & 0,702 & 0,254 & 0,393 \\
\hline Karaca ve: Karay, 2017 & 0,471 & 0,318 & 0,101 & $-0,153$ & 1,095 & 1,490 & 0,139 \\
\hline Mokaram A Stukistat, vd. & 1,273 & 0,306 & 0,094 & 0,673 & 1,873 & 4,158 & 0,000 \\
\hline A Maszi, 2018 & 1,252 & 0,168 & 0,028 & 0,923 & 1,581 & 7,4489 & 0,000 \\
\hline Kim vd., 2016 & 0,303 & 0,124 & 0,015 & 0,060 & 0,546 & 2,444 & 0,015 \\
\hline Karay ve Köksd, 2009 & 0,415 & 0.211 & 0,045 & 0,001 & 0,829 & 1,963 & 0,050 \\
\hline Kasato ve Ozcan, 2010 & 1,684 & 0,357 & 0,128 & 0,964 & 2,364 & 4,658 & 0,000 \\
\hline Erdoteni vd, 2009 & 0,967 & 0,281 & 0,079 & 0,415 & 1,518 & 3,436 & 0,001 \\
\hline Yangin, 2014 & 0,442 & 0,163 & 0,027 & 0,121 & 0,762 & 2,703 & 0,007 \\
\hline Kyned vd, 2016 & 0,560 & 0,316 & 0,100 & $-0,080$ & 1,179 & $1,7 \pi 0$ & 0,077 \\
\hline Densay ve Ylldrim, 2017 & 0,095 & 0.207 & 0,043 & $-0,310$ & 0,501 & 0,461 & 0,645 \\
\hline Sayar ve Hanurou, 2018 & 0,141 & 0.227 & 0,052 & $-0,305$ & 0,597 & 0,620 & 0,536 \\
\hline Varzaneh ve Bưralocie, 2015 & 1,708 & 0,212 & 0,045 & 1,292 & 2,124 & 8,045 & 0,000 \\
\hline Yu-Stari Chang, 20139 & 0,148 & 0,199 & 0,036 & $-0,224$ & 0,516 & 0,774 & 0,439 \\
\hline Yu-Stan Chang, 20130 & 0,461 & 0,191 & 0,037 & 0,086 & 0,835 & 2,411 & 0,016 \\
\hline Olger ve Ýmer, 2013 & 0,841 & 0,243 & 0,059 & 0,363 & 1,318 & 3,453 & 0,001 \\
\hline \multirow[t]{2}{*}{ Karateq ve Ozcan, 2015} & 0,638 & 0,294 & 0,087 & 0,061 & 1.215 & 2,167 & 0,030 \\
\hline & 0,631 & 0,095 & 0,009 & 0,445 & 0,818 & 6.631 & 0,000 \\
\hline
\end{tabular}

Hedges's $\mathrm{g}$ and $95 \% \mathrm{Cl}$
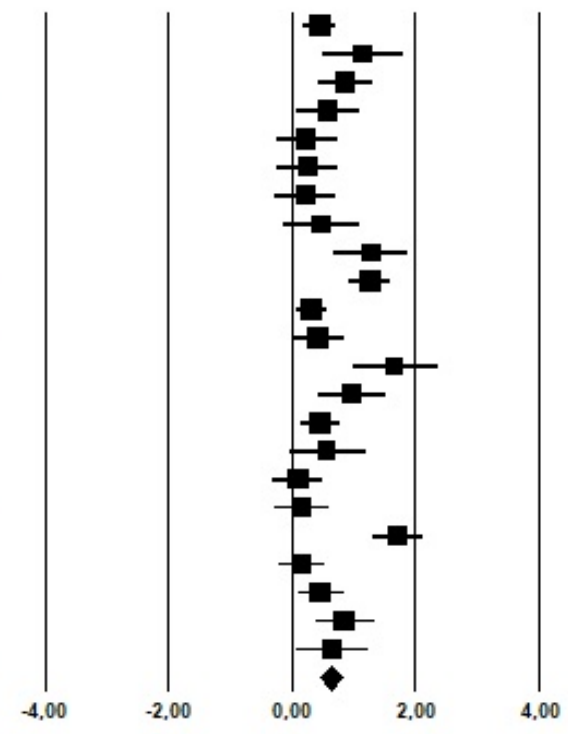

Şekil 5. Çalışmaların orman grafiği

Şekil 5'te yer alan orman grafiğine göre en büyük etki büyüklüğüne sahip çalışma Varzaneh ve Baharlooie'nin (2015) çalışması iken, en düşük etki büyüklügüne sahip çalışma Şensoy ve Yıldırım'ın (2017) çalışmasıdır. Çalışmaların etki büyüklükleri \%95 güven aralığından anlamlılık düzeyi incelendiğinde, 15 karşılaştırmanın etki büyüklüklerinin anlamlı olduğu ( $p \leq .05)$; 8 karşılaştırmanın etki büyüklüklerinin anlamlı olmadığı ( $p>05$ ) görülmektedir. Araştırmaya dahil edilen 19 çalışmanın (23 karşılaştırma) etki büyüklükleri rastgele etkiler modeline göre birleştirildiğinde 0.095 standart hata ve \%95 güven aralığının alt sınıı 0.445 ve üst sınırı 0.818 ile etki büyüklüğü değeri 0.631 olarak hesaplanmıştır. Bu değer Cohen'in (1988) sınıflamasına göre "orta" düzeyde bir etki büyüklüğüdür. Buna göre öğretim strateji, yöntem ve tekniklerinin yaratıcı düşünme becerisine orta düzeyde bir etkiye sahip olduğu söylenebilir.

\section{Moderatör Analizi}

Meta-analize dahil edilen çalışmaların yayınlandığı ülkelerin toplam etki büyüklüğüne etkisinin belirlenmesi amacıyla, rastgele etkiler modeline göre yapılan kategorik moderatör analizi sonuçları Tablo 7'de verilmiştir.

Tablo 7.

Çalışmaların Yayınlandığı Ülkeye Göre Moderatör Analizi Sonuçları

\begin{tabular}{|c|c|c|c|c|c|c|c|c|c|}
\hline \multirow{2}{*}{\multicolumn{2}{|c|}{ Değişken }} & \multirow{2}{*}{$\mathbf{N}$} & \multirow{2}{*}{$\begin{array}{c}\text { Etki } \\
\text { Büyüklüğüu }\end{array}$} & \multirow{2}{*}{ Std. Hata } & \multicolumn{2}{|c|}{ \%95 Güven Aralıkları } & \multicolumn{3}{|c|}{ Heterojenlik } \\
\hline & & & & & Alt limit & Üst limit & $\mathbf{Q}$ & df & $p$ \\
\hline \multirow{5}{*}{$\stackrel{\mathscr{\vartheta}}{\bar{\Xi}}$} & Türkiye & 13 & 0.608 & 0.101 & 0.411 & 0.806 & & & \\
\hline & İran & 5 & 0.602 & 0.313 & -0.011 & 1.215 & & & \\
\hline & Tayvan & 2 & 0.302 & 0.157 & -0.006 & 0.610 & & & \\
\hline & Diğer & 3 & 0.919 & 0.371 & 0.191 & 1.647 & & & \\
\hline & Toplam & 23 & 0.543 & 0.080 & 0.386 & 0.700 & 3.825 & 3 & 0.281 \\
\hline
\end{tabular}


Tablo 7'de görüldüğg̈ üzere çalışmaların yayınlandığı ülkeye göre oluşturulan grupların etki büyüklükleri arasında istatistiksel olarak anlamlı bir farklılığın bulunmadığı $(Q=3.825 ; p>05)$ ortaya çıkmıştır. Bu sonuç öğretim strateji, yöntem ve tekniklerinin yaratıcı düşünmeye etkisinin, çalışmanın yayınlandığı ülkeye göre değişmediğini göstermektedir.

Meta-analize dahil edilen araştırmalardaki çalışma gruplarının öğrenim kademesinin toplam etki büyüklüğü üzerindeki etkisinin belirlenmesi amacıyla, rastgele etkiler modeline göre yapılan kategorik moderatör analizi sonuçları Tablo 8'de verilmiştir. Okul öncesi kademesinde sadece bir çalışma (Dikici Sığırtmaç, 2016) bulunması nedeniyle, bu çalışma analizden çıkarılmıştır.

Tablo 8.

Çalışma Grubunun Öğrenim Kademesine Göre Moderatör Analizi Sonuçları

\begin{tabular}{|c|c|c|c|c|c|c|c|c|c|}
\hline \multirow{2}{*}{ Değişken } & & \multirow{2}{*}{$\mathbf{N}$} & \multirow{2}{*}{$\begin{array}{c}\text { Etki } \\
\text { Büyüklüğü }\end{array}$} & \multirow{2}{*}{$\begin{array}{l}\text { Std. } \\
\text { Hata }\end{array}$} & \multicolumn{2}{|c|}{ \%95 Güven Aralıkları } & \multicolumn{3}{|c|}{ Heterojenlik } \\
\hline & & & & & Alt limit & Üst limit & $\mathbf{Q}$ & df & $p$ \\
\hline \multirow{5}{*}{ 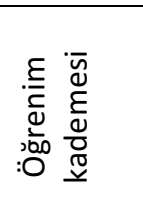 } & Ortaokul & 10 & 0.516 & 0.099 & 0.322 & 0.710 & & & \\
\hline & Üniversite & 6 & 0.635 & 0.177 & 0.288 & 0.982 & & & \\
\hline & Lise & 3 & 1.217 & 0.279 & 0.669 & 1.765 & & & \\
\hline & ilkokul & 3 & 0.260 & 0.116 & 0.033 & 0.487 & & & \\
\hline & Toplam & 22 & 0.487 & 0.067 & 0.355 & 0.619 & 11.466 & 3 & 0.00 \\
\hline
\end{tabular}

Tablo 8'de görüldüğü üzere çalışma grubunun öğrenim kademesine göre oluşturulan grupların etki büyüklükleri arasında istatistiksel olarak anlamlı bir farklılığın ( $Q=11.466 ; p<.05)$ olduğu ortaya çıkmıştır. En büyük etki büyüklüğünün 1.217 ile lisede öğrenim gören öğrencilerle yürütülen çalışmalarda, en düşük etki büyüklüğünün ise 0.260 ile ilkokulda öğrenim gören öğrencilerle yürütülen çalışmalarda olduğu görülmektedir. Bu sonuç öğretim strateji, yöntem ve tekniklerinin yaratıcı düşünmeye etkisinin çalışma grubunun öğrenim kademesine göre değiştiğini göstermektedir. Meta-analize dahil edilen çalışmalarda ele alınan disiplinlerin toplam etki büyüklüğüne etkisinin belirlenmesi amacıyla, rastgele etkiler modeline göre yapılan kategorik moderatör analizi sonuçları Tablo 9' da verilmiştir.

Tablo 9.

Çalışılan Disipline Göre Moderatör Analizi Sonuçları

\begin{tabular}{|c|c|c|c|c|c|c|c|c|c|}
\hline \multirow{2}{*}{\multicolumn{2}{|c|}{ Değişken }} & \multirow{2}{*}{$\mathbf{N}$} & \multirow{2}{*}{$\begin{array}{c}\text { Etki } \\
\text { Büyüklüğü }\end{array}$} & \multirow{2}{*}{$\begin{array}{l}\text { Std. } \\
\text { Hata }\end{array}$} & \multicolumn{2}{|c|}{ \%95 Güven Aralıkları } & \multicolumn{3}{|c|}{ Heterojenlik } \\
\hline & & & & & Alt limit & Üst limit & $\mathbf{Q}$ & df & $p$ \\
\hline \multirow{7}{*}{ 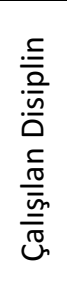 } & Eğitim Bilimleri & 7 & 0.574 & 0.170 & 0.240 & 0.908 & & & \\
\hline & Fen Bilimleri & 5 & 0.399 & 0.084 & 0.235 & 0.563 & & & \\
\hline & Sanat Eğitimi & 5 & 0.423 & 0.126 & 0.176 & 0.670 & & & \\
\hline & Sosyal Bilgiler & 2 & 0.840 & 0.287 & 0.278 & 1.402 & & & \\
\hline & Dil Eğitimi & 2 & 1.462 & 0.227 & 1.016 & 1.907 & & & \\
\hline & Diğer & 2 & 0.896 & 0.175 & 0.554 & 1.238 & & & \\
\hline & Toplam & 23 & 0.562 & 0.057 & 0.450 & 0.675 & 25.289 & 5 & 0.00 \\
\hline
\end{tabular}

Tablo 9'da görüldüğü üzere çalışmalarda ele alınan disiplinlere göre oluşturulan grupların etki büyüklükleri arasında istatistiksel olarak anlamlı bir farklılığın $(Q=25.289 ; p \leq .05)$ olduğu ortaya çıkmıştır. En büyük etki büyüklüğünün 1.462 ile dil eğitimine yönelik yapılan çalışmalarda, en düşük etki büyüklüğünün ise 0.399 ile fen bilimlerine yönelik yapılan çalışmalarda olduğu görülmektedir. Bu sonuç öğretim strateji, yöntem ve tekniklerinin yaratıcı düşünmeye etkisinin ele alınan disipline göre değiştiğini göstermektedir.

Meta-analize dahil edilen çalışmalarda uygulanan öğretim yöntem ve tekniğinin toplam etki büyüklüğü üzerindeki etkisinin belirlenmesi amacıyla, rastgele etkiler modeline göre yapılan kategorik moderatör analizi yapılmış ve sonuçlar Tablo 10'da verilmiştir. Moderatör analizi sürecinde öncelikle, 
araştırmalarda uygulanan öğretim yöntem ve teknikleri aktif öğrenme stratejileri ve bilişsel etkinleştirme stratejileri olarak gruplandırılmıştır. Aktif öğrenme stratejileri kategorisinde probleme dayalı öğrenme, öyküleştirme, işbirlikli öğrenme, araştırma inceleme gibi strateji ve yöntemleri uygulayan araştırmalar yer alırken, bilişsel etkinleştirme stratejileri kategorisinde beyin fırtınası, altı şapka düşünme, Van Hiele Modeli ve Porphyrios Ağacı tekniklerini uygulayan araştırmalar yer almaktadır.

Tablo 10.

Çalışılan Disipline Göre Moderatör Analizi Sonuçları

\begin{tabular}{|c|c|c|c|c|c|c|c|c|c|}
\hline \multirow{2}{*}{ Değişker } & & \multirow{2}{*}{$\mathbf{N}$} & \multirow{2}{*}{$\begin{array}{c}\text { Etki } \\
\text { Büyüklüğüü }\end{array}$} & \multirow{2}{*}{$\begin{array}{l}\text { Std. } \\
\text { Hata }\end{array}$} & \multicolumn{2}{|c|}{ \%95 Güven Aralıkları } & \multicolumn{3}{|c|}{ Heterojenlik } \\
\hline & & & & & Alt limit & Üst limit & $\mathbf{Q}$ & df & $p$ \\
\hline \multirow{4}{*}{ 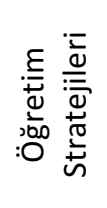 } & Aktif Öğrenme & 17 & 0.559 & 0.106 & 0.352 & 0.767 & & & \\
\hline & Stratejileri & & & & & & & & \\
\hline & $\begin{array}{c}\text { Bilişsel Etkinleştirme } \\
\text { Stratejileri }\end{array}$ & 6 & 0.841 & 0.201 & 0.447 & 1.235 & & & \\
\hline & Toplam & 23 & 0.621 & 0.094 & 0.437 & 0.804 & 1.533 & 1 & 0.216 \\
\hline
\end{tabular}

Tablo 10'da görüldüğü üzere çalışmalarda uygulanan öğretim strateji, yöntem ve tekniğine göre oluşturulan grupların etki büyüklükleri arasında istatistiksel olarak anlamlı bir farklılığın $(Q=1.533$; p>.05) bulunmadığı ortaya çıkmıştır. Bu sonuç öğretim strateji, yöntem ve tekniklerinin yaratıcı düşünmeye etkisinin uygulanan öğretim strateji, yöntem ve tekniğine göre değişmediğini göstermektedir.

\section{Tartışma, Sonuç ve Öneriler}

Bu araştırmada öğretim strateji, yöntem ve tekniklerinin yaratıcı düşünmeye etkisinin belirlenmesi amaçlanmıştır. Yapılan meta analizle öğretim strateji, yöntem ve tekniklerinin öğrencilerin yaratıcı düşünme becerisi üzerinde orta düzeyde etkisi olduğu sonucuna ulaşılmıştır. Ayrıca öğretim strateji, yöntem ve tekniklerinin yaratıcı düşünmeye etkisi geleneksel olmayan öğretim yöntem ve tekniğine göre anlamlı farklııı göstermemektedir. Bunun anlamı öğrencinin aktif katılımına dayalı geleneksel olmayan strateji, yöntem ve tekniklerin yaratıcılığı geliştirme oranı birbirine yakındır. Bugün yaratıcılık üzerine çalışan araştırmacıların ortak kanısı yaratıcılığın geliştirilebilir bir özellik olduğudur (Aerila \& Rönkkö 2013; Burbiel, 2009; Robinson, 2017). Yaratıcılık zihnin sezgisel olarak çalışmasını sağlayan, yaratıcı düşünme için uygun koşulların ve özgürlüğün sağlandığı destekleyici bir ortama ihtiyaç duyan bir süreçtir (Wang, Peck \& Chern, 2010). Öğretim uygulamaları bu destekleyici ortamın değişkenleri olarak yer almaktadır. Lin ve Wu'ya (2016) göre, öğrencilerinin öğrenme sürekliliğini yenilikçi ve yaratıcı öğretim yöntemleriyle sağlayan öğretmenler için yaratıcılık eğilim haline gelmiştir. Yaratıcılık birçok faktörden etkilenen bir yapı gösterir. OECD (2019), yaratıcı düşünme sürecinin sınıflarda başarı, gelişim, bireysel ve sosyal olanaklarla bağlantılı olduğunu belirtmektedir. San (2003), yaratıcı zekanın ve yaratıcılık yetisinin kalıtımdan ve çevresel faktörlerden etkilendiğini ifade etmektedir. Bu durumda öğretim etkinliklerinin yaratıcılığı açıklayan tek faktör olarak sayılması doğru değildir. Şayet, yaratııılık sadece öğretim yöntemleriyle açıklansaydı yaratıcılı̆̆ı desteklemek için geliştirilen tüm öğretim uygulamalarının yaratıcı düşünme üzerindeki etkisi anlamlı ve yüksek olurdu. Örneğin, Kanlı ve Emir (2013), ortaokul fen bilimleri dersinde gerçekleştirdikleri araştırmalarında yaratıcı düşünme becerisi üzerinde probleme dayalı öğrenmenin etkisinin olmadığı sonucuna ulaşmışlardır. Yang, Lee, Hong ve Lin (2016) ise ortaokul fen bilimleri dersinde araştırma temelli öğrenmenin yaratıcı düşünmeyi etkilediği sonucunu elde etmişlerdir. Aynı ders, aynı eğitim kademesi ve aynı bağımsız değişkenin yaratıcılığa etkisinin incelendiği bu araştırmalarda farklı bulgular ortaya çıkmıştır. Nitekim öğrencilerin yaratıcı düşünme süreçleri üzerinde nelerin rol oynadığı ayrıca dikkate alınmalıdır. Problem çözme gereksinimi, öğretmenin yaratıcılığı, öğrencilerin içsel motivasyonu, kişiliği ve konuya 
ilgisi, öğretim yönteminin öğrenciye uygunluğu vb. birçok durumu düşünmek gerekir. Bu durumlar öğretim yöntemlerinin yaratıcı düşünme becerisine orta düzeydeki etkisini açıklayabilir.

Tienken (2013), herhangi bir ülkenin kendisini daha yaratıcı vatandaşlara sahip olmak için standardize edemeyeceğini ancak problem, proje ve etkinlik temelli programlar aracilığıyla öğrencilere yaratıcılıkla ilgili davranış ve becerilerin kazandırabileceğini söylemektedir. Araştırmada da öğretim strateji, yöntem ve tekniklerinin öğrencilerin yaratıcı düşünme becerisine etkisinin çalışmanın yapıldığı ülkeye göre anlamlı farklılık göstermediği sonucuna ulaşılmışır. AlMutairi (2015) beyin fırtınası tekniğinin Kuveyt'teki ortaokul 7. Sınıf öğrencilerinin yaratıcı düşünme becerileri üzerinde anlamlı etkisi olduğunu bulmuştur. Al Masri (2018) ise beyin fırtınası tekniğinin lise 10. sınıf öğrencilerinin yaratıcı düşünme becerileri üzerinde anlamlı etkisi olduğu bulgusunu elde etmiştir. Bu araştırmada meta analize de dahil edilen Tayvan, Türkiye, Güney Kore, Endonezya ve İran'da eğitim teknolojileri alanıyla ilgili çeşitli uygulamaların yaratıcı düşünme üzerindeki etkileri incelenmiş ve deney grubu yönünde anlamlı farklılık gözlemlenmiştir (Chang, 2013; Katırcı \& Satırcı, 2010; Kim, Park, Yoo \& Kim, 2016; Shabrina \& Kuswanta, 2018; Varzaneh \& Baharlooie, 2015). Verileri farklı ülkelerden toplanmış bu araştırma sonuçları incelendiğinde benzer bulgulara ulaşıldığı anlaşılmaktadır. Psikolojinin "Insan nasıl öğrenir ve nasıl düşünür?" sorusuna verdiği cevabı genellenebilir, olgusal ve evrenseldir. Eğitimciler de öğrencilerin yaratıcılıklarını güçlendirmek için psikolojiden aldıkları bilgilerle öğretim uygulamalarını geliştirmektedirler. Geliştirilen öğretim strateji, yöntem ve teknikleri dünyanın her yerinde aynı şekilde aynı amaçla uygulanmaktadır. Bu nedenle öğretim ilkelerine, amaçlarına uyularak takip edilen strateji, yöntem ve teknikler hangi ülkede uygulanırsa uygulansın öğrencileri benzer kazanımlara ulaştırabilir. Bu durumda öğretmenlere düşen iş, yaratıcı düşünmeyi teşvik eden koşulları ve öğrencilerin daha etkili nasıl yaratıcı düşünebileceklerini anlamaktır (OECD, 2019).

Araştırmadan elde edilen sonuçlar öğretim strateji, yöntem ve tekniklerinin öğrencilerin yaratıcı düşünme becerisine etkisinin öğrenim kademesine göre anlamlı düzeyde farklılaştığını göstermektedir. Çocuklardaki (3-18 yaş) yaratııılığın yaş dönemine göre seyri uzun süreli çalışmalarla ortaya çıkarılmıştır. Torrance (1963) geliştirdiği Yaratıcı Düşünce Testi ile yaptığı çalışmalarda (3-18 yaş), yaratııılığın genelde yaşla birlikte arttığını fakat bazı yaşlarda inişler gösterdiğini belirtmiştir (as cited in Yontar, 1993). Bu araştırmada ise en yüksek etkiye lise öğrencileri ile yürütülen çalışmalarda ulaşılırken, en düşük etki ilkokul öğrencileri ile yürütülen çalışmalarda görülmüştür. Jindal-Snape et al. (2013) yaratıcılığın öğrenciler üzerindeki etkilerini araştıran 2005 ve 2011 yılları arasındaki 18 ampirik çalışmayı çeşitli faktörler bağlamında incelemişlerdir. Araştırmada çocukların yaratııılık testlerindeki performanslarının ilkokul 2. sınıftan 4. sınıfa (7 ila 9 yaş) arttığı; 5 . sınıfta ise (yaş 10) ya sabitlendiği ya da azaldığı sonucuna ulaşılmıştır. Bu araştırmada da meta analize dahil olan ve ilkokul eğitim kademesinde yürütülen tüm çalışmalar ilkokul 4. ve 5. sınıf öğrencileriyle yürütülen araştırmalardır. Dolayısıyla her iki araştırma sonucu birbirini destekler niteliktedir. Ayrıca yaratııılığın artarak geliştiği teziyle tutarlııı göstermektedir. Farklı yaşlarda farklı yaratıcı özellikler gösterilmesinin, aynı yaşlarda yaratıcı eğilimlerin benzer olmamasının, bazen duraklamaların yaşanmasının nedenleri için çevresel faktörler düşünülebilir. Ülkelerin düşünme eğitimine verdiği önem, yaratıcı sınıf ortamlarının desteklenmesi, öğretmenlerin yaratıcı tutum ve uygulamaları, kültürün yaratıcılığa açıklı̆ı̆ öğrencilerin yaratıcı gelişimleri için destekleyici olabilir. Bu durumun aksine didaktik öğretimler, öğrencinin yerine alınan kararlar, gerçek yaşamdan uzak olan programlar, yapılandırmacı ve aktif öğrenme temelli öğretimle bağlantılı olmayan uygulamalar vb. faktörler ise yaratıcı gelişimleri engelleyebilir.

Araştırmada öğretim strateji, yöntem ve tekniklerinin öğrencilerin yaratıcı düşünme becerisine etkisinin çalışmada ele alınan disipline göre anlamlı olarak farklılaştığı sonucuna ulaşılmıştır. En yüksek etki dil eğitimi alanında yapılan çalışmalarda, en düşük etki fen bilimleri alanında yapılan çalışmalarda görülmüştür. Ghonsooly ve Showqi (2012) yabancı dil öğrenirken bilişsel esneklik, çalışan bellek gibi bilişsel işlevlerin geliştiğini ve bunun da yaratıcılı̆̆ı etkilediğini belirtmektedir. 
Özellikle okullarda yabancı dil öğrenirken akıcılık, özen, özgünlük ve esneklik gibi yaratıcılıkla ilgili bileşenlerin önemli ölçüde artırdığını ifade etmektedir. Piasecka'a göre (2018), öğrenciler yabancı dil sınıflarında emin olamayabilecekleri sözler yaratmakta ve üretebilme riskini alabilmektedir. Öğrenciler öğrenilen yabancı dile günlük yaşamda maruz kalmadıklarında zihinsel olarak daha çok çaba sarf edebilirler. Bu nedenle dil eğitimi yaratıcılığın gelişimini daha fazla tetikleyebilir. Fen bilimleri dersindeki öğrenme süreci daha yapılandııılmış olabilmektedir. Bu derste öğrenciler kendilerine verilen bilgiler ve yönergeler doğrultusunda keşif yaparlar. Bu durum en düşük etkinin fen bilimleri alanındaki çalışmalarda görülmüş olmasını açıklayabilir. Diğer taraftan fen bilimleri derslerinde genel olarak bilimsel yaratıcılık ön plandadır. Bilimsel yaratıcı düşünme sürecinde ortaya konan ürünün bilimsel doğrularla çelişmemesi ve işlevsel olması beklenir (Kutlu, Doğan \& Karakaya, 2010). Oysa bazı durumlarda yaratıcılık bilimsel gerçeklerle sınırlanmamalıdır. Hadzigeorgiou, Fokialis ve Kabouropoulou (2012) fen bilimlerinde, sanat ve bilimi uyarlamak yoluyla hem bilimin doğasına hem de genel yaratıcılık kavramıyla uyumlu bilimsel yaratıcılık kavramını aramanın önemli bir ihtiyaç olduğunu vurgulamıştır. Bu durum en düşük etkinin fen bilimleri alanında yapılan çalışmalarda görülmüş olmasını açıklayabilir.

Araştırmada sonuç olarak öğretim strateji, yöntem ve tekniklerinin öğrencilerin yaratıcı düşünmelerini orta düzeyde etkilediği anlaşılmıştır. Ayrıca öğretim strateji, yöntem ve tekniklerinin yaratıcı düşünme üzerindeki etkisinin uygulanan öğretim etkinliklerinin türüne ve araştırmanın yapıldığı ülkeye göre anlamlı farklılık göstermediği görülmüştür. Ancak öğrenim kademesine ve çalışılan disiplin türüne göre öğretim uygulamalarının yaratıcılığı etkileme düzeyinin farklılaştığı tespit edilmiştir. Bu sonuçlar doğrultusunda aşağıdaki öneriler getirilmiştir:

- Bu araştırma 2005 ve 2019 yılları arasındaki ERIC, Google Scholar, TR Dizin veri tabanlarında taranan çalışmalarla sınırlıdır. Başka çalışmalarda Scopus, Taylor ve Francis, Springer, HW.Wilson, Science Direct gibi uluslar arası eğitim veri tabanları taranabilir ve ampirik çalışmalar bu kapsamda yeniden incelenebilir. Ayrıca araştırmada sadece makaleler dahil edilmiş, tezler kapsam dışında tutulmuştur. Tezlerin de dahil olabileceği çalışmalar tasarlanabilir.

- Bu araştırmada öğretim strateji, yöntem ve tekniklerinin öğretim kademesine, uygulama türüne, çalışılan disipline, araştırmanın yapıldığı ülkeye göre yaratıcı düşüme üzerindeki etkisinin belirlenmesi amaçlanmıştır. Başka çalışmalarda örneklem büyüklüğü, ölçme araçlarının yapısı, araştırmadaki uygulama süresi gibi değişkenler bağlamında hatta aynı ölçme aracıyla ölçüm yapılan çalışmalar için analizler yapılabilir.

- Bu araştırmada genel olarak "yaratıcı düşünme" nin gelişimine odaklanmış çalışmalar üzerinde durulmuştur. Farklı çalışmalarda bilimsel yaratııılık, matematiksel yaratıcılık, sanatta yaratıcılık vb. bağımlı değişkenleri etkileyen öğretim uygulamalarına yönelik araştırmalar üzerinde durulabilir.

- Araştırmada öğretim strateji, yöntem ve tekniklerinin öğrencilerin yaratıcı düşünme becerisi üzerinde orta düzeyde bir etkiye sahip olduğu görülmüştür. Başka çalışmalarda yaratıcılığın etkilediği ve etkilendiği motivasyon, ilgi, yaratıcı öğrenme ortam, öğretmen tutumu, kişilik vb. faktörler incelenebilir.

- Öğretim strateji, yöntem ve teknikleri yaratıcı düşünmeyi geliştiren önemli çevresel faktörler arasındadır 


\section{References}

Aerila, J. \& Rönkkö, M. (2015). Integrating literature with craft in a learning process with creative elements. Early Childhood Education Journal, 43, 89-98. doi: 10.1007/s10643-013-0626-1

Akbaş, U., Atalan Ergin, D., \& Tatlı, C. (2019). The effect of gender on problematic internet usage: A meta-analysis. Addicta: The Turkish Journal on Addictions, 6(2), 361-386. doi: 10.15805/addicta.2019.6.2.0064

Al Masri, A. (2018). The impact of using brainstorming in the development of creative thinking and achievement in the English language of the 10th grade students at King Abdullah II Schools of excellence in Amman. International Education Studies, 12(2), 82-92. doi: 10.5539/ies.v12n2p82

Allen, A. P. \& Thomas, K. E. (2011). A dual process account of creative thinking, Creativity Research Journal, 23(2), 109-118. doi: 10.1080/10400419.2011.571183

AlMutairi, A. N. M. (2015). The effect of using brainstorming strategy in developing creative problem solving skills among male students in Kuwait: A field study on Saud Al-Kharji School in Kuwait city. Journal of Education and Practice, 6(3),136-145.

Beghetto, R. A., Kaufman, J. C., \& Baer, J. (2015). Teaching for creativity in the common core classroom. New York: Teachers College Press.

Bono, E. D. (1999). Six thinking hats. Grand Rapids, MI: Back Bay Books.

Burbiel, J. (2009). Creativity in research and development environments: A practical review. International Journal of Business Science and Applied Management, 4(2), 35-51.

Buzan, T. \& Buzan, B. (2011). Zihin haritaları. İstanbul: Alfa Yayıncılık.

Büyüköztürk, Ş., Kılıç Çakmak, E., Akgün, Ö. E., Karadeniz, Ş., \& Demirel, F. (2014). Bilimsel araştırma yöntemleri (18. bs.) Ankara: Pegem Yayıncılık.

Card, N. A. (2012). Applied meta-analysis for social science research. New York, London: Guilford Press.

Cash, H., Rae, C. D., Steel, A. H., \& Winkler, A. (2012). Internet addiction: A brief summary of research and practice. Current Psychiatry Reviews, 8(4), 292-298. doi: 10.2174/157340012803520513

Chakera, S. \& Tao, S. (Eds.). (2019). UNICEF Education Think Piece Series: Innovative thinking for complex educational challenges in the SDG4 era. Nairobi: UNICEF Eastern and Southern Africa Regional Office.

Chang, Y., Li, B. D., Chen, H. C., \& Chiu, F. C. (2015). Investigating the synergy of critical thinking and creative thinking in the course of integrated activity in Taiwan. Educational Psychology, 35(3), 341-360. doi: 10.1080/01443410.2014.920079

Chang, Yu-S. (2013). Student technological creativity using online problem-solving activities. International Journal of Technology and Design Education, 23(3),803-816. doi: 10.1007/s10798012-9217-5

Cohen, J. (1988). Statistical power analysis for the behavioral sciences (2nd ed.). Hillsdale, NJ: Lawrence Earlbaum Associates.

Craft, A. (2001). An analysis of research and literature on creativity in Education: Report prepared for the Qualifications and Curriculum Authority. Retrieved January 02, 2020, from http://www.creativetallis.com/uploads/2/2/8/7/2287089/creativity_in_education_report.pdf 
Csikszentmihalyi, M. (1997). Creativity: Flow and the psychology of discovery and invention. New York: Harper Collins Publishers.

Damanpour, F. \& Schneider, M. (2009). Characteristics of innovation and innovation adoption in public organisations: Assessing the role of managers. Journal of Public Resources and Theory, 19(3) 495-522. doi: 10.1093/jopart/mun021

Dikici Sığırtmaç, A. (2016). An investigation on the effectiveness of chess training on creativity and theory of mind development at early childhood. Educational Research and Reviews,11(11), 10561063. doi: $10.5897 /$ ERR2016.2676

Dinçer, S. (2014). Eğitim bilimlerinde uygulamalı meta-analiz. Ankara: Pegem Yayıncılık.

Egger, M. Smith, G. D., Schneider, M., \& Minder, C. (1997). Bias in meta-analysis detected by a simple, graphical test. British Medical Journal, 315(7109), 629-634. doi: 10.1136/bmj.315.7109.629

Erdoğan, T., Akkaya, R., \& Akkaya, S. Ç. (2009). The effect of the van hiele model based instruction on the creative thinking levels of 6th grade primary school students. Educational Sciences: Theory \& Practice, 9(1), 161-194.

Forrester, J. C. (2008). Thinking creatively; thinking critically. Asian Social Studies, 4(5), 100-105. doi: $10.5539 /$ ass.v4n5p100

Ghonsooly, B. \& Showqi, S. (2012). The effects of foreign language learning on creativity. English Language Teaching, 5(4), 161-167. doi: 10.5539/elt.v5n4p161

Gilbert, S. W. (1992). Systematic questioning: Taxonomies that develop critical thinking skills. Science Teacher, 59(9), 41-46. Retrieved January 02, 2020, from https://eric.ed.gov/?id=EJ456460

Goclowska, M. A. \& Crisp, R. J. (2013). On counter-stereotypes and creative cognition: When interventions for reducing prejudice can boost divergent thinking. Thinking Skills and Creativity, 8(2013), 72-79. doi: 10.1016/j.tsc.2012.07.001

Hadzigeorgiou, Y., Fokialis, P., \& Kabouropoulou, M. (2012). Thinking about creativity in science education. Creative Education, 3(05), 603-611. doi: 10.4236/ce.2012.35089.

Harris, R. (1998). Introduction to creative thinking. Retrieved January 02, 2020, from https://www.virtualsalt.com/crebook1.htm

Horng, J., Hong, J., Chanlin, L., Chang, S., \& Chu, H. (2005). Creative teachers and creative teaching strategies. International Journal of Consumer Studies, 29(4), 352-358. doi: 10.1111/j.14706431.2005.00445.x

Jeffrey, B. \& Craft, A. (2004). Teaching creatively and teaching for creativity: Distinctions and relationships. Educational Studies, 30(1), 77-87. doi: 10.1080/0305569032000159750

Jindal-Snape, D., Davies, D., Collier, C., Howe, A., Digby, R., \& Hay, P. (2013). The impact of creative learning environments on learners: A systematic literature review. Improving Schools, 16(1), 2131. doi: $10.1177 / 1365480213478461$

Kampylis, P. \& Berki, E. (2014). Nurturing creative thinking. Retrieved January 02, 2020, from https://unesdoc.unesco.org/ark:/48223/pf0000227680

Kanli, E. \& Emir, S. (2013). The effect of problem based learning on gifted and normal students' achievement and creativity levels. Necatibey Faculty of Education Electronic Journal of Science and Mathematics Education, 7(2), 18-45. doi: 10.12973/nefmed201 
Karaca, T. \& Koray, Ö. (2017). The effect of using the creative reversal act in science education on middle school students' creativity levels. Eurasian Journal of Educational Research, 67(2017), 199-214. doi: 10.14689/ejer.2017.67.12

Karataş, S. \& Özcan, S. (2010). The effects of creative thinking activities on learners' creative thinking and project development skills. Ahi Evran University Journal of Kırşehir Education Faculty,11(1), 225-243.

Karataş, S. \& Özcan, S. (2015). The effect of creative activities in cooperative learning environment on students' creative and critical thinking and their academic achievement. Journal of Educational Technology Theory and Practice, 5(2), 1-21. doi: 10.17943/etku.56500

KatırCI, E. \& SatıcI, A. F. (2010). Interactive physics programında simülasyon ve portfolyo uygulamalarının akademik benlik ve yaratıclık üzerine etkisi. Journal of Turkish Science Education, 7(4), 46-59.

Keun, L. L. \& Hunt, P. (2006). Creative dance: Singapore children's creative thinking and problemsolving responses. Research in Dance Education, 7(1), 35-65. doi: 10.1080/14617890600610661

Kıncal, R. Y., Avcu, Y. E., \& Kartal, O. Y. (2016). The effects of creative thinking activities on learners' creative thinking skills and academic achievement. Journal of Theoretical Educational Science, 9(1), 15-37. doi: 10.5578/keg.9722

Kim, H. J., Park, J. H., Yoo, S., \& Kim, H. (2016). Fostering creativity in tablet-based interactive classrooms. Educational Technology \& Society, 19(3), 207-220.

Kind, P. M. \& Kind, V. (2007). Creativity in science education: Perspectives and challenges for developing school science. Studies in Science Education, 43(1),1-37. doi: 10.1080/03057260708560225

Koray, Ö. \& Köksal, M. S. (2009). The effect of creative and critical thinking based laboratory applications on creative and logical thinking abilities of prospective teachers. Asia-Pacific Forum on Science Learning and Teaching, 10(1), 1-13.

Ku, Y. L. \& Kuo. C. L. (2014). Develop a framework of creative thinking teaching mode for RN-BSN students on the basis of the creative process of clinical nurses in Taiwan. Innovations in Education and Teaching International,53(4), 424-434. doi: 10.1080/14703297.2014.949282

Kupers, E., Lehmann-Wermser, A., McPherson, G., \& van Geert, P. (2019). Children's creativity: A theoretical framework and systematic review. Rev Educ Res., 89(1), 93-124. doi: 10.3102 /0034654318815707

Kutlu, Ö., Doğan, C. D., \& Karakaya, í. (2010). Öğrenci başarısının belirlenmesi: Performansa ve portfolyoya dayalı durum belirleme. Ankara: Pegem Yayıncilık.

Lin, C. S. \& Wu, R. Y. W. (2016). Effects of web-based creative thinking teaching on students' creativity and learning outcome. Eurasia Journal of Mathematics, Science \& Technology Education, 12(6), 1675-1684. doi: 10.12973/eurasia.2016.1558a

Lin, W. L. \& Shih, Y. S. (2016). Designing EEG neurofeedback procedures to enhance open-ended versus closed-ended creative potentials. Creativity Research Journal, 28(4), 458-466. doi: 10.1080/10400419.2016.1229979

Lipman, M. (1995). Moral education, higher-order thinking and philosophy for children. Early Child Development and Care, 107(1), 61-70. doi: 10.1080/0300443951070108

Low, A. (2006). Creative thinking. World Futures, 62(6), 455-463. doi: 10.1080/02604020600798635 
Marušić, M. \& Sliško, J. (2014). High-school students believe school physics helps in developing logical but not creative thinking: Active learning can change this idea. European Journal of Physics Education, 5(4), 30-41.

Ministry of Education Singapore (MoES). (2020). Education. Retrieved February 12, 2020, from https://www.moe.gov.sg/education/

Ministry of National Education (MoNE). (2020). Öğretim programları. Retrieved February 12, 2020, from http://mufredat.meb.gov.tr/

Mokaram, Al-A. K., Al- Shabatat, A. M., Fong, F. S., \& Abdallah, A. A. (2011). Enhancing creative thinking through designing electronic slides. International Education Studies, 4(1), 39-43.

Organisation for Economic Co-operation and Development (OECD). (2015). The innovation imperative: Contributing to productivity, growth and well-being. Paris, OECD Publishing. doi: 10.1787/9789264239814-en

Organisation for Economic Co-operation and Development (OECD). (2016). Teaching strategies for instructional quality. Retrieved December 03, 2019, from http://www.oecd.org/education/school/TALIS-PISA-LINK-teaching_strategies_brochure.pdf

Organisation for Economic Co-operation and Development (OECD). (2019). PISA 2021 creative thinking framework (third draft). Retrieved December 03, 2019, from https://www.oecd.org/pisa/publications/PISA-2021-creative-thinking-framework.pdf

Perry, A. \& Karpova, E. (2017). Efficacy of teaching creative thinking skills: A comparison of multiple creativity assessments. Thinking Skills and Creativity, 24(2017), 118-126. doi: 10.1016/j.tsc.2017.02.017

Piasecka L. (2018). Tinker, Tailor...: Creativity in foreign language learning and teaching. In M. Pawlak \& A. Mystkowska-Wiertelak (Eds.), Challenges of second and foreign language education in a globalized World (pp.89-106). Springer, Cham.

Rábanos, N. L. \& Torres, P. A. (2012). Effects of a program for developing creative thinking skills. Electronic Journal of Research in Educational Psychology, 10(3), 1139-1158. Retrieved from https://eric.ed.gov/?id=EJ997680

Reiman, A. J. \& Dotger, B. H. (2008). What does innovation mean for moral educators? Journal of Moral Education, 37(2), 151-164. doi: 10.1080/03057240802009124

Rezaei, A. \& Zakariaie, M. (2011). Exploring the impact of handcraft activities on the creativity of female students at the elementary schools. International Education Studies, 4(1), 127-133.

Robinson, K. (2017). Out of our minds: The power of being creative. West Sussex: John Wiley \& Sons Ltd.

Sak, U. \& Oz, O. (2010). The effectiveness of the creative reversal act (CREACT) on students' creative thinking. Thinking Skills and Creativity, 5(1), 33-39. doi: 10.1016/j.tsc.2009.09.004

San, i. (2003). Yaratıcılıkta temel kavramlar. In A. Öztürk (Ed.), Çocukta yaratıcılık ve drama (pp. 1-14). Eskişehir: Anadolu University Yayıncılık.

Sayan, Y. \& Hamurcu, H. (2018). The effects of the materials develeoped for the fourth grade science and technology course to the students' skills of creative thinking skills and self-concepts. Education Sciences (NWSAES), 13(2), 106-120. doi: 10.12739/NWSA.2018.13.2.1C0683

Shabrina, S. \& Kuswanto, H. (2018). Android-assisted mobile physics learning through indonesian batik culture: Improving students' creative thinking and problem solving. International Journal of Instruction, 11(4), 287-302. 
Shaughnessy, M. F. (1998). An interview with E. Paul Torrance: About creativity. Educational Psychology Review, 10(4), 441-452. doi: 10.1023/A:1022849603713

Shelby, L. B. \& Vaske, J. J. (2008). Understanding meta-analysis: A review of the methodological literature. Leisure Sciences, 30(2), 96-110. doi: 10.1080/01490400701881366

Stenberg, A. (2017). What does innovation mean-a term without a clear definition. Retrieved October 12, 2020, from http://hh.diva-portal.org/smash/get/diva2:1064843/FULLTEXT01.pdf

Sternberg, R. J. (2003). Creative thinking in the classroom. Scandinavian Journal of Educational Research, 47(3), 325-338. doi: 10.1080/00313830308595

Sternberg, R. J. (2006). The nature of creativity. Creativity Research Journal, 18(1), 87-98.

Sungur, N. (1997). Yaratıcı düşünce. İstanbul: Evrim Yayıncılık.

Şensoy, Ö. \& Yıldırım, H. I. (2017). Effects of inquiry based learning approach on creative thinking and scientific process skills. Cumhuriyet International Journal of Education-CIJE, 6(1), 34-46. doi: 10.30703/cije.321434

Tan, A. G. (2000). A review of the study creativity in Singapore. Journal of Creative Behaviour, 34(4), 259-284. doi: 10.1002/j.2162-6057.2000.tb01215.x

Taylor, S. P. (2017). What is innovation? A study of the definitions, academic models and applicability of innovation to an example of social housing in England. Open Journal of Social Sciences, 5, 128 146. doi: $10.4236 /$ jss.2017.511010

Thurlings, M., Evers, A. T., \& Vermeulen, M. (2014). Toward a model of explaining teachers' innovative behavior: A literature review. Review of Educational Research, 85(3), 430-471. doi: 10.3102/0034654314557949

Tienken, C. H. (2013). International comparisons of innovation and creativity. Kappa Delta Pi Record, 49, 153-155. doi: 10.1080/00228958.2013.845501

Torrance, E. P. (1965). Scientific views of creativity and factors affecting its growth. Daedalus 94(3), 663-681. Retrieved October 12, 2020, from http://www.jstor.org/stable/20026936

Torrance, E. P. (1972). Can we teach children to think creatively? Retrieved October 12, 2020, from https://files.eric.ed.gov/fulltext/ED061544.pdf

Torrance, E. P. (2018). Torrance tests of creative thinking: Interpretive manual. Retrieved October 12, 2020, from https://www.ststesting.com/gift/TTCT_InterpMOD.2018.pdf

Ülger, K. \& Imer, Z. (2013). The effect of problem based learning (pbl) approach on students' creative thinking ability. H. U. Journal of Education, 28(1), 382-392.

Varzaneh, S. S. \& Baharlooie, R. (2015). The effect of virtual vs. traditional classroom instruction on creative thinking of Iranian high school efl learners. English Language Teaching, 8(5), 177-188. doi: $10.5539 /$ elt.v8n5p177

Wang, S., Peck, K. L., \& Chern, J. (2010). Difference in time influencing creativity performance between design and management majors. International Journal of Technology and Design Education, 20, 77-93. doi: 10.1007/s10798-008-9059-3

Wojciechowski, M. \& Ernst, J. (2018). Creative by nature: Investigating the impact of nature preschools on young children's creative thinking. The International Journal of Early Childhood Environmental Education, 6(1), 3-20. Retrieved October 12, 2020, from https://files.eric.ed.gov/fulltext/EJ1193490.pdf 
Yaman, S. \& Yalçın, N. (2005). Effectiveness on creative thinking skills of problem based learning approach in science teaching. Elemantary Education Online, 4(1), 42-52.

Yang, K., Lee, L., Hong, Z., \& Lin, H. (2016). Investigation of effective strategies for developing creative science thinking. International Journal of Science Education, 38(13), 2133-2151. doi: 10.1080/09500693.2016.1230685

Yangın, S. (2014). The effect of porphyrios tree based activities on classroom prospective teachers' thinking abilities. Turkish Studies- International Periodical For The Languages, Literature and History of Turkish or Turkic,9(2), 1597-1620.

Yarbrough, N. D. (2016) Assessment of creative thinking across cultures using the Torrance tests of creative thinking (ttct): Translation and validity issues. Creativity Research Journal, 28(2), 154164. doi: 10.1080/10400419.2016.1162571

Yıldıım, R. (2002). Yaratıcılık ve yenilik (3. bs.). İstanbul: Sistem Yayıncılık.

Yiğit, E. Ö. \& Erdoğan, T. (2008). Sosyal bilgiler dersinde uygulanan öyküleştirme yönteminin ilköğretim altıncı sınıf öğrencilerinin yaratıcı düşünme düzeylerine etkisi. Ç.Ü. Sosyal Bilimler Enstitüsü Dergisi, 17(3), 399-416.

Yontar, A. (1993). Insanda yaratıcılığın gelişimi. In A. Atalay (Ed.), Yaratıclık ve eğitim (pp.15-36). Ankara: Türk Eğitim Derneği Yayıncılığı.

Ziadat, A. H. \& Al-Ziyadat, M. T. (2015). The effectiveness of training program based on the six hats model in developing creative thinking skills and academic achievements in the Arabic language course for gifted and talented Jordanian students. International Education Studies, 9(6), 150-157. doi: 10.5539/ies.v9n6p150 